6-3-2016

\title{
Towards a Theory of Displacement Atrocities: The Cherokee Trail of Tears, The Herero Genocide, and The Pontic Greek Genocide
}

Andrew R. Basso

University of Calgary

Follow this and additional works at: https://digitalcommons.usf.edu/gsp

\section{Recommended Citation}

Basso, Andrew R. (2016) "Towards a Theory of Displacement Atrocities: The Cherokee Trail of Tears, The Herero Genocide, and The Pontic Greek Genocide," Genocide Studies and Prevention: An International Journal: Vol. 10: Iss. 1: 5-29.

DOI:

http://dx.doi.org/10.5038/1911-9933.10.1.1297

Available at: https://digitalcommons.usf.edu/gsp/vol10/iss1/5

This is brought to you for free and open access by the Open Access Journals at Digital Commons @ University of South Florida. It has been accepted for inclusion in Genocide Studies and Prevention: An International Journal by an authorized editor of Digital Commons @ University of South Florida. For more information, please contact digitalcommons@usf.edu. 
Towards a Theory of Displacement Atrocities: The Cherokee Trail of Tears, The Herero Genocide, and The Pontic Greek Genocide

\section{Acknowledgements}

I would like to thank Dr. Rhoda E. Howard-Hassmann, Dr. Maureen S. Hiebert, and the editors of Genocide Studies and Prevention for their invaluable and critical insights on this project. 


\title{
Towards a Theory of Displacement Atrocities: The Cherokee Trail of Tears, The Herero Genocide, and The Pontic Greek Genocide
}

\author{
Andrew R. Basso \\ University of Calgary \\ Calgary, Alberta, Canada
}

\begin{abstract}
This article examines how displacement is used as a tool of atrocity perpetration and offers initial observations that will be used to create a future typology of Displacement Atrocities. Perpetrators' uses of forced population displacement coupled with systematic deprivations of vital daily needs (i.e., food, water, clothing, shelter, and medical care) combine to kill targeted victims through primarily indirect methods. A preliminary theoretical framework of Displacement Atrocities is offered and the critical elements that comprise this crime are explored. I argue that the Displacement Atrocity crime is a new way of understanding lethal forced population displacement. This theoretical framework is used to examine three typically understudied atrocities: the Cherokee Trail of Tears, the Herero Genocide, and the Pontic Greek Genocide. These processes of destruction are all classified as examples of Displacement Atrocities. This article is part of a larger research project on Displacement Atrocities to be completed in the coming years.
\end{abstract}

Keywords: atrocity, genocide, displacement, indirect killing, vital human needs, Cherokees, Hereros, Pontic Greeks

\section{Introduction}

The question 'How and why do perpetrators utilize displacement as a tool to commit atrocities against a targeted people?' yields a multi-layered and complex array of responses. This type of crime should be called a Displacement Atrocity (DA). Contemporary studies of human rights violations and atrocities often focus on the prevention and punishment of crimes with little attention paid to theorizing about the killing processes themselves and why perpetrators select some methods of killing over others). ${ }^{1}$ There have been many single-case studies of atrocities that included displacement as a method of killing, but all have been explored on the individual case level and rarely strive to create theory. ${ }^{2}$ These single-case studies of individual crimes juxtapose with attempts at building universal theories to account for how and why atrocities are committed, which can often be too broad and create variables that can account for almost anything or are too abstract to be pragmatically applied. ${ }^{3}$

Rather than focus on a single case or universal account, this paper seeks to construct a midrange theory of a specific killing process used in atrocity crimes. This targeted study offers insights into methods of displacement killings tied together in theory form, something lacking in current comparative atrocity scholarship. Approaching atrocities at a mid-range theory level between single-case studies and universalist accounts is critical moving forward in atrocity scholarship. This article represents an initial attempt at understanding how displacement is used as a tool to commit atrocities and is part of a broader ongoing research project.

Research has been conducted through a comparative political science lens and provides a structural account of atrocities, a strongly suggested research agenda within the Oxford Handbook

\footnotetext{
${ }^{1}$ Benjamin Lieberman, "From Definition to Process," in New Directions in Genocide Research, ed. Adam Jones (New York: Routledge, 2012), 3-17 and Adam Jones, "Genocide and Structural Violence," in New Directions in Genocide Research, ed. Adam Jones (New York: Routledge, 2012), 132-152.

${ }^{2}$ Michael D. Green, The Cherokee Removal: A Brief History with Documents (New York: Bedford/St. Martin's Press, 2005), Horst Drechsler, "Let Us Die Fighting": The Struggle of the Herero and Nama Against German Imperialism (1884-1915) (London: Zed Press, 1980), Tessa Hofmann, “Cumulative Genocide: The Massacres and Deportations of the Greek Population of the Ottoman Empire (1912-1923)," in The Genocide of the Ottoman Greeks: Studies on the State-Sponsored Campaign of Extermination of the Christians of Asia Minor (1912-1922) and Its Aftermath: History, Law, Memory, eds. Tessa Hofmann, et al. (Sarsdale: Melissa International Ltd, 2011), and Joyce Apsel, "Research and Teaching about Genocide: history, challenges and new directions," in Genocide Matters: Ongoing Issues and Emerging Perspectives, eds. Joyce Apsel and Ernesto Verdeja (New York: Routledge, 2012), 3-5.

${ }^{3}$ Ben Kiernan, Blood and Soil: A World History of Genocide and Extermination from Sparta to Darfur (New Haven: Yale University Press, 2007), Mark Levene, Genocide in the Age of the Nation State, Vol.1: The Meaning of Genocide (London: I.B. Tauris, 2005), and Lieberman, "From Definition to Process," 5-8.
} 
of Genocide Studies. ${ }^{4}$ This structural approach seeks to connect multiple cases of atrocities instead of treating them as isolated events and to examine how, "elites, political parties, bureaucracies, armed forces, and paramilitaries" are all connected in atrocity perpetration. ${ }^{5}$ This paper presents the beginnings of a typological theory of DA crimes using approaches and methodologies best outlined by Alexander L. George and Andrew Bennett in Case Studies and Theory Development in the Social Sciences, a standard text in qualitative comparative political research programmes. ${ }^{6}$ Within this approach, a most different case selection is employed, with the goal of linking typically understudied cases that each illuminate different kinds of DA crimes. The cases exemplify the diverse range of policy and policy implementation, government type, and geography, among many other elements, that comprise DA crimes.

A DA crime encapsulates the processes of forced population displacement and systemic deprivations of vital human needs (i.e., food, water, clothing, shelter, and medical care) to destroy populations in whole or in part. The DA crime is first defined and situated within contemporary scholarship and international legal frameworks. The five characteristic stages of the DA crime are then presented and outlined theoretically with few empirical examples. Following this, the DA framework is applied empirically to three atrocity cases that are typically understudied and have not been previously linked: the Cherokees in the United States of America (USA) (18381839), Hereros in German Southwest Africa (GSWA) (1904-1908), and the Pontic Greeks in the Ottoman Empire (1916-1918 and 1919-1923). ${ }^{7}$ All cases followed systemically similar steps of DA perpetration including displacement as the main method of killing despite other available options.

\section{Defining and Situating 'Displacement Atrocity'}

The definition of DA crimes that I have developed and will use in this paper is:

A Displacement Atrocity is a type of killing process employed against a targeted population defined by the perpetrators which uniquely fuses forced population displacement and primarily indirect deaths resulting from the displacement and systemic deprivations of vital human needs to destroy a group in whole or in part.

The most critical component of the DA crime process is the primary use of indirect killing methods, e.g., systemic deprivations, to accomplish the population destruction desired by the perpetrators. DA crime theory is distinctly linked with genocide by attrition, first identified by Helen Fein. With the attrition concept, Fein intended to explain killing via indirect methods, sparking a new branch of atrocity research. ${ }^{8}$ More recent examples of applying attrition to atrocity cases have been completed by Eric Reeves and Samuel Totten to explain the crimes against Darfurians and the Nuba in Sudan, and by Sheri Rosenberg and Everita Silina as a framework to explain and link a number of other cases. ${ }^{9}$ However, what current genocide by attrition literature mostly neglects is the examination and understanding of the displacement process utilized in atrocities, something it had originally intended to accomplish. This DA crime study provides an explicitly targeted understanding of displacement processes to fill this gap in theory.

\footnotetext{
${ }^{4}$ Donald Bloxham and A. Dirk Moses, The Oxford Handbook of Genocide Studies (New York: Oxford University Press, 2010), i-v and 1-18.

${ }^{5}$ Anton Wiess-Wendt, "The State and Genocide," in The Oxford Handbook of Genocide Studies, eds. Donald Bloxham and A. Dirk Moses (New York: Oxford University Press, 2010), 99-100.

${ }^{6}$ Alexander George and Andrew Bennett, Case Studies and Theory Development in the Social Sciences (Cambridge, Massachusetts: MIT Press, 2004), 205-262.

${ }^{7}$ Green, The Cherokee Removal, Drechsler, 'Let Us Die Fighting', and Hofmann, “Cumulative Genocide."

${ }^{8}$ Helen Fein, "Genocide by Attrition 1939-1993: The Warsaw Ghetto, Cambodia, and Sudan: Links between Human Rights, Health, and Mass Death," Health and Human Rights 2, no. 2 (1997), 10-13.

${ }^{9}$ Eric Reeves, "Genocide by Attrition: Agony in Darfur," Dissent, 52, 1 (2005), Samuel Totten, Genocide by Attrition: The Nuba Mountains of Sudan (New Brunswick: Transaction Publishers, 2012), and Sheri P. Rosenberg and Everita Silina, "Genocide by Attrition: Silent and Efficient," in Genocide Matters: Ongoing Issues and Emerging Perspectives, eds. Joyce Apsel and Ernesto Verdeja (London: Routledge, 2013).
} 
The DA term was originally conceptualized in my previous research as 'Displacement Genocide' ${ }^{10}$ However, David Scheffer's work influenced my decision to replace 'genocide' with 'atrocity' because of the encumbered, charged, and largely dogmatic (sometimes unproductive and stagnant) debates over what groups are protected under the 1948 Convention on the Prevention and Punishment of the Crime of Genocide. ${ }^{11}$ To avoid labelling problems, an initial interest in writing this article was not labelling 'genocide', 'crimes against humanity', or 'war crimes' to any of the cases explored, but rather to strictly identify and understand the displacement killing processes themselves as 'atrocities'. However, it became readily apparent that the identification of the DA type of killing required an exploration of its implications for international law at the very least. While I certainly do not present an exhaustive list, nor a full exploration of how DA crimes could be codified as crimes in international law, further research programmes into how DA crimes fit within the present international legal regime can and should be a priority.

Article 6 of the Rome Statute of the International Criminal Court reiterates the 1948 Convention on the Prevention and Punishment of the Crime of Genocide. ${ }^{12}$ Within this crime, I argue that understanding Article 6(c) should include not just aspects of starvation and disease as conditions inflicted on a group to bring about its destruction (see Helen Fein's identification of genocide by attrition for a further elaboration on these concepts) but also displacement as a tool perpetrators utilize to destroy a group in whole or in part. ${ }^{13}$ This is not a completely new way of understanding the conditions of life clause in the Genocide Convention, rather it is a different and expanded way of understanding deliberately inflicted conditions to bring about group destruction.

In terms of Crimes Against Humanity, Article 7 of the Rome Statute, I believe there should be a new understanding of extermination (Article 7(1)(b)) that allows for lethal displacement to be tried as a crime. According to the Rome Statute, "'extermination' includes the intentional infliction of conditions of life, inter alia the deprivation of access to food and medicine, calculated to bring about the destruction of part of a population." ${ }^{14}$ DA crimes should be considered part of the inter alia due to their deadly outcomes. While Article $7(1)(\mathrm{d})$ on deportation or forcible transfer of population seems to cover the DA crime, it differs slightly in that the DA crime is better described as a process of extermination via displacement, not just displacement for the sake of displacing or cleansing a people from a given territory.

Finally, Article 8 of the Rome Statute proscribes War Crimes. In this Article, there are no acts listed that outline the DA crime. Because of this, there should be a new crime defined within War Crimes that includes the DA crime definition and elements outlined in this article. There are multiple crimes within Article 8(2)(a)(b)(e) that could describe DA crimes, but they do not explicitly delineate acts that are similar to DA crimes. ${ }^{15}$

While it may be stated that DA crimes and ethnic cleansing are very similar, there are a few problems with the latter concept. First, comparing the two is a difficult enterprise because ethnic cleansing is primarily concerned with cleansing an area, not necessarily killing a population (which is the focus of the DA crime). Second, there are multiple, nebulous definitions for ethnic cleansing and it is difficult to triangulate which one holds the most intellectual weight. Finally, ethnic cleansing is not a crime in international law. While it has been referenced in some ICTY cases, it is a crime without clear definition and legal applicability. ${ }^{16}$

\footnotetext{
${ }^{10}$ Andrew Basso, “Dying as Exiles: Deportation Genocide Theory and the Relationship Between Displacement and Genocide" (Master's Thesis, Wilfrid Laurier University, 2013) and Andrew Basso, "Towards a Displacement Atrocities Theory: The Cherokee, Herero, and Pontic Greeks" (paper presented at the Eleventh Meeting of the International Association of Genocide Scholars, Winnipeg, Manitoba, July 2014).

${ }^{11}$ David Scheffer, "Genocide and Atrocity Crimes," Genocide Studies and Prevention, 1, no. 3 (2006), David Scheffer, “The Merits of Unifying Terms: 'Atrocity Crimes' and 'Atrocity Law'," Genocide Studies and Prevention 2, no. 1 (2007), Convention on the Prevention and Punishment of the Crime of Genocide, General Assembly, New York, 9 December 1948, no.1021, and Lieberman, "From Definition to Process," 3-17.

${ }^{12}$ United Nations, Rome Statute of the International Criminal Court (last amended 2010), 17 July 1998, ISBN No. 92-9227-227-6.

${ }^{13}$ Ibid. and Fein, "Genocide by Attrition."

${ }^{14}$ United Nations, Rome Statute.

${ }^{15}$ Ibid.

${ }^{16}$ Norman Naimark, Fires of Hatred: Ethnic Cleansing in Twentieth-Century Europe (Cambridge: Harvard University Press,
} 


\section{Elements of Displacement Atrocities}

DA crimes have five key facets that warrant further elaboration. These are: a defined targeted group, a responsibility for deaths, a displacement over a large territory, the distinction between indirect and direct killing, and necessary and sufficient variables for a DA label.

\section{A Defined Targeted Group}

Contributing to an earlier scholarly and legal debate about which groups are protected under the genocide convention and other definitions is not the intent of this mid-range theory paper, but these schools of thought require recognition. Unlike hardline legal and centre camps that seek to protect the uniqueness of the term 'genocide' or specifically delineate groups that are protected, a liberal scholar camp argues for redefining what groups are protected and how they can be defined. ${ }^{17}$ This paper is predicated on the ideas of the latter group of scholars, those in the liberal camp, who postulate that any group as defined by the perpetrators can be subjected to atrocities generally, which does not necessarily require a rigid definition of groups, and genocide specifically. ${ }^{18}$ Perpetrators can exogenously, or targets can endogenously, conceptualize their own existence - the broad literature on ethnicity, race, nationalism, and groups is helpful for understanding the fluidities and non sequiturs of group identity, formation, and inclusion/exclusion. ${ }^{19}$ How the perpetrators view the targeted group is, ultimately, the crucial element in understanding why the group is being destroyed.

\section{Responsibility for Deaths}

DA crimes can be understood as either genocide, crimes against humanity, or war crimes. Certainly if a verdict of genocide is to be rendered then a dolus specialis must be proven for an intent to destroy a group in whole or in part as such. ${ }^{20}$ However, crimes against humanity and war crimes do not have the special intent threshold that genocide requires. Perhaps then, we can understand a DA crime as either intended, born out of recklessness, or as unintended. In all three situations, a DA is still an atrocity crime and still deserving of individual criminal prosecution at the International Criminal Court and in domestic courts. Perpetrators can discriminate among targets directly (for example, by removing men from communities as part of the DA crime process) and indirectly (meaning the perpetrator policy does not discriminate among targets). Perpetrators inflict conditions of life that at the very least will foreseeably lead to mass death or at the maximum are fully intended outcomes to destroy groups as such. This is best demonstrated by systematic deprivations of vital human needs. It is reasonable to assume that perpetrators know if individuals are not fed, clothed, and sheltered, then they will die. If policies are implemented to deprive individuals of these things during an exhausting displacement, it is reasonable to assert that perpetrators knew they would die as a result of these policies and conditions.

2001), Michael Mann, The Dark Side of Democracy: Explaining Ethnic Cleansing (New York: Cambridge University Press, 2005), Nicolas Werth, "Mass Deportations, Ethnic Cleansing, and Genocidal Politics in the Later Russian Empire and the USSR," in The Oxford Handbook of Genocide Studies, eds. Donald Bloxham and A. Dirk Moses (New York: Oxford University Press, 2010), 386-406, and Prosecutor v. Krstić, Appeals Chamber Judgment, 19 April 2004, IT-98-33-A.

${ }^{17}$ William Schabas, “Genocide Law in a Time of Transition: Recent Developments in the Law of Genocide," Rutgers Law Review 61, no. 1 (2008), 164-178, Larry May, Genocide: A Normative Account (New York: Cambridge University Press, 2010), 1-22, Steven T. Katz, The Holocaust in Historical Context: Volume 1: The Holocaust and Mass Death Before the Modern Age (New York: Oxford University Press, 1994), 42-58, Leo Kuper, Genocide: Its Political Use in the Twentieth Century (New Haven: Yale University Press, 1982), 120, Frank Chalk and Kurt Jonassohn, The History and Sociology of Genocide: Analyses and Case Studies (New Haven: Yale University Press, 1990), 35, Martin Shaw, What is Genocide? (Malden: Polity Press, 2007), 154, and Helen Fein, Genocide: A Sociological Perspective (London: Sage Publications Ltd., 1993$), 23$.

${ }^{18}$ Fein, Genocide, 23 and Chalk and Jonassohn, The History and Sociology of Genocide, 35.

${ }^{19}$ Stuart J. Kaufman, Modern Hatreds: The Symbolic Politics of Ethnic War (Ithaca: Cornell University Press, 2001), Anthony Marx, Making Race and Nation (New York: Cambridge University Press, 1998), Benedict Anderson, Imagined Communities: Reflections on the Origin and Spread of Nationalism (Los Angeles: University of California Press, 1985), and Joel Migdal, Strong Societies and Weak States: State-Society Relations and State Capabilities in the Third World (Princeton: Princeton University Press, 1988).

${ }^{20}$ May, Genocide, 97-156 and Robert Cryer, et al., An Introduction to International Criminal Law and Procedure (New York: Cambridge University Press, 2010), 206-227. 
Displacement Over Open Territory

Open territory can be described as a land mass that has few if any human communities. This type of territory is typically far removed from metropolitan areas. The land is inhospitable to human survival and can best be described as underdeveloped. This territory typically has few usable resources for the displaced peoples to use for survival and if resources exist, perpetrators have typically denied victims the opportunity to exploit these resources. ${ }^{21}$ The vastness of the open territory is conducive to forced marches, displacements, and other forced removal actions that are designed to kill a victim population away from the prying eyes of witnesses in urban and more developed rural areas.

A key distinction needs to be clarified regarding the difference between linear distance and total area. For DA crimes, perpetrators have in the past exploited both linear distance and total area to commit their atrocities. As will be demonstrated in the cases below, the Germans displaced the Herero into the Namib and Kalahari Deserts, places that are not necessarily overwhelming in linear distance from border to border, but are vast in terms of area squared.$^{22}$ The Cherokees in the Southern USA were marched over 1,900 kilometres from the Carolinas to Illinois to Oklahoma, and the Pontic Greeks were marched from the Black Sea coastline to Der Zor, over 800 kilometres in linear distance..$^{23}$ All three of these DA examples are indicative of the strategic uses of space perpetrators have exploited and, theoretically, demonstrate that displacement does not necessarily have to occur in a place of vast linear distance; it can occur in a place that is simply vast in area. In both scenarios, linear distance and total area, the ultimate goal of population destruction is accomplished due to the path of displacement and the magnitude of the distance travelled either in a line or in an area.

The open territories utilized by perpetrators is a principal defining aspect of a DA as victims are displaced to these types of territories instead of stationary killing centres like the extermination camps in Poland during the National Socialist Genocides. ${ }^{24}$ The goal of a DA is to utilize displacement as the primary killing method. This becomes especially evident in death marches, forced exposure to elements, and the systemic denial of vital human needs during displacement in multiple territorial locations. The large displacement in either linear distance or area causes physical exhaustion, conceals the killing process from potential objectors and saviours, and limits the possibilities for victim group resistance.

There is a relationship between space and time in DA crimes as well, as evidenced by a contrast between Serb-perpetrated crimes and killing in former Yugoslavia in the 1990s and the three cases under study in this article. The Cherokee, Herero, and Pontic Greek populations experienced death at substantially higher rates than Serb-targeted Croat, Muslim, and Kosovar Albanian populations in former Yugoslavia. The key differences may be spatial and temporal. First, Serb crimes were perpetrated in densely-populated areas and the spaces to which groups were displaced to were small in comparison to the relatively wide, open geography of North America, the Namib Desert, and Anatolia. ${ }^{25}$ Temporally, Serb crimes were committed over a number of years, but there was a defining deficiency in time used to perpetrate crimes in comparison to the expansive amounts of time the Americans, Germans, and Turks devoted to killing the Cherokees, Hereros, and Pontic Greeks, respectively. ${ }^{26}$ It could be reasonably stated that if the Serbs possessed larger territories and more time, then the death rates for Croats, Muslims, and Kosovar Albanians would have been significantly higher than they were.

\footnotetext{
${ }^{21}$ Allan D. Cooper, The Geography of Genocide (New York: University Press of America, 2009), 70.

${ }^{22}$ Drechsler, 'Let Us Die Fighting', 17 and 89.

${ }^{23}$ John Ehle, Trail of Tears: The Rise and Fall of the Cherokee Nation (New York: Doubleday Publishing Group, Inc., 1988), 350389 and Hofmann, "Cumulative Genocide," 39-84.

${ }^{24}$ Saul Friedländer, The Years of Extermination: Nazi Germany and the Jews (New York: HarperCollins, 2007).

${ }^{25}$ Norman Cigar, Genocide in Bosnia: The Third Balkan War, Third Revised Edition (College Station: Texas A\&M University Press, 1995), 27-29.

${ }^{26}$ David Rodhe, Endgame: The Betrayal and Fall of Srebrenica, Europe's Worst Massacre Since World War II (Boulder: Westview Press, 1998), 317-396.
} 
Distinguishing Between Indirect and Direct Deaths

The DA crime uniquely fuses forced population displacement most often with primarily indirect killing methods. Direct methods are utilized only as a secondary feature to atrocity perpetration. The types of atrocities perpetrated on the victims will now be outlined. Indirect killing methods began to be systematically studied following Fein's identification of genocide by attrition - methods beyond direct killing that bring about the destruction of a population in whole or in part. ${ }^{27}$ Indirect killings can theoretically be described as practices that do not include physical violence from perpetrators against victims, but rather systemic deprivations that bring about the destruction of victims. Practically, these methods can include, but are not limited to, starvation and/or dehydration; creating conditions conducive to the spread of disease; exposure to natural world elements, i.e., the heat or the cold; and inhumane maltreatments that lead to eventual death, i.e., deaths resulting from exhaustion on forced marches. ${ }^{28}$ These indirect methods can be referred to as a systematic deprivation of vital human needs coupled with an exacerbation of the outcomes of these deprivations leading to large-scale demographic losses in the targeted group(s). This type of killing requires a significantly longer period of time to kill one person compared to direct killing. Conversely, indirect killing may be more cost effective and less time consuming to kill entire populations as the entire group may be displaced and destroyed at the same time, unlike direct killing methods where it takes years to kill millions in gas chambers, for example.

Direct killing, in contrast, includes any deaths that occur due to direct physical violence. These are much more 'traditionally' studied killing patterns - the Einsatzgruppen killing squads on the Eastern Front, the gas chambers at the extermination camps during the National Socialist Genocides, and Interahamwe killing squads in 1994 Rwanda. ${ }^{29}$ Direct killing methods can include such tactics as fatal gunshot wounds, blade or blunt instrument strikes, gassings, and immolation. These practices cause nearly instantaneous deaths, ultimately more time efficient than indirect forms of killing, but certainly more costly due to the need for materiel to construct and outfit the machinery of death.

Perpetrators may uniquely combine these two killing practices during a DA. As will be discussed later, one of the key purposes of a DA is to reduce costs on perpetrating regimes, so indirect killing is favoured over direct killing for the simple economics of destruction. It can cost extraordinary amounts of human power, materiel, and money to commit atrocities if direct killing is selected as the primary method of destruction compared to indirect methods. Indirect and direct methods are different but can be utilized in conjunction.

\section{Displacement Atrocities: Necessary and Sufficient Variables}

One necessary element of DA crime theory is the open territory which allows killing to occur away from the awareness of others. The second necessary feature is indirect killing methods utilized against the displaced targeted population. When these two variables are combined, they meet the criteria to deem a process of systematically killing a targeted group, a DA. What is not necessary, but may be present, are direct killing methods. Direct killing methods are supplemental to the sufficient combination of displacement and indirect deaths. Direct killing sometimes occurs, but what is most vital to understanding displacement atrocities is the systematic deprivations of vital human needs, the weakened human bodies that result from these deprivations, and the deaths that are then caused by these deprivations exacerbated by forced displacements. Ultimately, the responsibility for not providing these vital human needs rests with the perpetrators, as the targeted group would not have been forcibly displaced had it not been for the malicious goals of the perpetrators - whether this be ethnic homogenization, ideology, religious difference, or territorial cleansing.

\footnotetext{
${ }^{27}$ Fein, "Genocide by Attrition," 10-45 and Totten, Genocide by Attrition, 2.

${ }^{28}$ Fein, "Genocide by Attrition," 10-45 and Totten, Genocide by Attrition, 2.

${ }^{29}$ Friedländer, The Years of Extermination, 13 and Jean Hatzfeld, Machete Season: The Killers in Rwanda Speak (New York: Farrar, Straus, and Giroux, 2005), 10-20.
} 


\section{Perpetrator Perspectives: Using Displacement}

Why would perpetrators select displacement to commit atrocities? Logical speculations can begin to answer this question. This article offers four central reasons for why the DA crime is selected as the optimal mode of destruction: the cost-effectiveness of DA-style killing, the ability to lessen psychological strains on individual perpetrators, the pervasive social disruption among victim groups, and veiling the public.

\section{Cost-Effectiveness}

Of all the methods of killing available to perpetrators, DA-style killing is perhaps the most cost-effective. It requires so little of perpetrators. They exploit the natural world for the deadly environment it can be without food, water, shelter, clothing, and medical care as perpetrators exhaust victims to rapidly increase death rates. The perpetrators merely need to displace a population without these vital human needs and protect themselves while leaving the victims' bodies to deteriorate. Humans can survive up to 30 or 40 days without food, but this is only if they are hydrated. If they are not, and if they are being physically exerted, then the body degrades at a significantly faster rate. ${ }^{30}$ If minor sustenance is provided, the body can survive for longer, but physical exertion and exposure to the natural world without vital human needs being met causes fatal bodily deterioration or fatal ailments such as heat stroke. ${ }^{31}$ Without question, extreme weather (heat; cold; storms, including dust, rain, and tornadic events; droughts, and flooding) can exacerbate bodily deterioration leading to death or instant mortality. ${ }^{32}$

When hope is lost for survival, a negative psychological impact is seen on resilience and endurance. ${ }^{33}$ Perpetrators exploit the fragility of the mind and actively work to degrade the body, deprive individuals of vital human needs, compel massive physical exertion, and attempt to psychologically destroy their targets. These factors create the indirect killing aspect of DA. These are highly cost-effective because the only requirement of perpetrators is that they forcibly displace a population and control them, a practice that does not necessarily require many perpetrators and almost none of the materiel for direct killing. In this case, perpetrators simply leave their targets to die of deprivations and exhaustion. Financial restraints during wartime can impact the choice of killing methods, necessitating the selection of DA as the method of destruction due to its limited need for resources. Creating conditions conducive to the spread of disease via the deprivation of vital human needs is also cost-effective for perpetrators as this only requires negative action (leaving victims to die), not positive action (actively killing them via direct methods).

\section{Mental Strain on Perpetrators}

There is a substantial definitional and philosophical difference between 'dying' and 'being killed'. Dying implies an endogenous naturalness to death; killing implies an unnatural, intended, and exogenous act that causes death at the hands of another. ${ }^{34}$ There is a fine but distinct line between dying and killing. The nuanced nature of indirect deaths by systemic deprivations of vital human needs is a systemic process of killing, not merely victims dying of their own accord.

Studies on perpetrators have demonstrated that directly killing another human has caused serious mental stresses on the killers, something that may not be as prevalent among perpetrators of a DA crime. ${ }^{35}$ Perpetrators are directly responsible for the murders they commit

\footnotetext{
${ }^{30}$ Michael Peel, “Hunger Strikes,” BMJ 315, No. 7112 (1997), 829-830.

${ }^{31}$ Ibid.

${ }^{32}$ Jeffrey Berko, et al., "Deaths Attributed to Heat, Cold, and Other Weather Events in the United States, 2006-2010," National Health Statistics Reports 76 (2014), 1-16.

${ }^{33}$ Ervin Staub, The Psychology of Good and Evil: Why Children, Adults, and Groups Help and Harm Others (New York: Cambridge University Press, 2003), 289-418.

${ }^{34}$ Angus Stevenson and Maurice Waite (eds). Concise Oxford English Dictionary (New York: Oxford University Press, 2011), 398-399, 447, and 782, Will Cartwright, "Killing and Letting Die: A Defensible Distinction," British Medical Bulletin 52, no. 2 (1996), 354-361, and Helen Frowe, "Killing John to Save Mary: a Defence of the Moral Distinction Between Killing and Letting Die," in Topics in Contemporary Philosophy: Action, Ethics and Responsibility, eds. Joseph Keim Campbell, et al. (Cambridge: The MIT Press, 2007), 47-66.

${ }^{35}$ Christopher Browning, Ordinary Men: Reserve Police Battalion 101 and the Final Solution in Poland (New York:
} 
- the gunshot, blade strike, and floggings they inflict cause death right in front of their eyes. DA perpetrators, however, may be provided with a reduced recognition of their responsibility for the destruction of targets whom they forcibly displace. The systematic conditions of life meant to destroy groups obscure traditional understandings of killing. The victims of a DA crime 'die' along the route of displacement but these deaths are, undoubtedly, killing. While DA perpetrators do not directly murder targets, the conditions they impose ensure that all perpetrators have to do is simply leave victims to die. More research is needed on the psychological differentiations, if any, between mental stresses on perpetrators in direct killing versus indirect killing campaigns.

\section{Displacement as Social Disruption}

One goal of a DA, and atrocities more broadly speaking, is to disrupt the social bonds and networks of targeted groups so atrocities are easier to commit. This extermination of social fabrics is an idea best explored by Feierstein with his conceptualization of genocidal social practices. ${ }^{36}$ This concept can be readily expanded to instances of forced displacement as a tool to disrupt routinized and familiar social patterns of targeted groups. Displacement is one of the ultimate forms of disruption - it rips individuals away from their homes, familiar places, and people, and takes away any and all authority they had over their lives. Almost all common bonds are destroyed which disorients the targets and disrupts social bonds that could lead to resistance and efforts that could delay atrocity plans. ${ }^{37}$ Displacement disorients targets and may contribute to feelings of helplessness. In typical DA crimes, perpetrators separate men from women, weakening social fabrics. The displacement process means that individuals lose control of their world, reinforcing again the psychological control that perpetrators hold over the targets.

By displacing the targets, the killing process is moved away from victim community centres that could offer resistance, such as cities. These types of territories can cause many problems for an army, and perpetrators systematically avoid these types of environments by displacing targets to more open, unpopulated landscapes so the targets are easy to control and guide. Displacement to foreign lands also means that targets have less terrain knowledge and have a general inability to gather resistance resources, i.e., weapons, ammunition, and supplies, hindering resistance even further. Relocation decreases opportunities for targets to escape death; if they escape the displacement, they are in the middle of unfamiliar terrain and often face death due to survival problems. By displacing targets away from populated areas, there are fewer opportunities for the hiding of targets by saviours as well.

\section{Veiling the Public}

By moving the killing process outside of densely populated areas, perpetrators actively attempt to hide their crimes - a critical initial step in genocide/atrocity denial. Ironically, even if a population becomes incensed against the victim group(s), the killing process itself may upset bystanders and has the potential for making saviours/rescuers, objectors, or reformers out of even true believers. ${ }^{38}$ The experience of violence and suffering can change opinions so removing the process away from prying eyes is a requirement. Instead, hiding the evidence of atrocity becomes remarkably easy for perpetrators: the dead are strewn about sparsely-populated routes of displacement where the victims fall, bodies decompose and are consumed by the natural world, and victims can dig unmarked mass graves never to be found. The killing process, while perpetrated in vast spaces, is hidden and secretive (by very nature of it being farther removed from populated centres) giving another layer of deniability to the crimes.

\footnotetext{
HarperCollins, 1995), 221, James Waller, Becoming Evil: How Ordinary People Commit Genocide and Mass Killing (New York: Oxford University Press, 2007), iv-xiv and 267-280, and Hatzfeld, Machete Season, 157-164.

${ }^{36}$ Daniel Feierstein, "The Concept of 'Genocidal Social Practices'," in New Directions in Genocide Research, ed. Adam Jones (New York: Routledge, 2012), 18-36.

${ }^{37}$ Ibid.

${ }^{38}$ Staub, The Psychology of Evil, 289-418.
} 


\section{Choosing Displacement}

If a perpetrating regime has access to a large open territory that is generally uninhabited, does not want to expend mass resources on atrocities, and desires to keep its crimes hidden without associated costs of mass graves and body disposal, then it is understandable why regimes select this type of killing. From the perpetrator perspective, it makes sense to select this killing pattern over, for example, the highly bureaucratized and mechanical workings of the National Socialists. Perpetrators may also select displacement as a method of killing as a contingency if other modes of killing are not feasible to implement, possibly due to physical/geographical or materiel limitations. Not all political decisions can be explained through instrumental or bounded rationality. ${ }^{39}$ Rather, the context in which decisions are made can influence the outcomes of decisions - something I have attempted to demonstrate. There may be a correlation between different macro-historical processes such as colonialism and the choice to utilize DA crimes as a solution to perceived problems, but these questions require significant further research beyond the scope of this article. However, there are some reasons why perpetrators would not select DA crimes.

\section{Perpetrator Perspectives: Not Using Displacement}

Why perpetrators would utilize DA crimes to exterminate a population is one aspect of this style of killing, but perhaps a more important avenue of understanding is why perpetrators would not select displacement and indirect methods of killing. There are four central reasons why a perpetrating group may not select DA as an optimal mode of killing: territorial limitations; factoring for demographic density; the cost-effectiveness: time available ratio; and the cost-effectiveness: associated risks ratio.

\section{Territorial Limitations}

If a perpetrator group does not have access to an open, largely uninhabited territory, then a DA is very difficult to implement. Territories that resemble the American West, the open deserts of Namibia, and the vastness of the Turkish heartland are optimal areas to implement a DA. Areas that resemble the former Yugoslavia, East/Central Europe, the Canadian Rockies, and dense rainforests in South America are suboptimal for implementing a DA, but that does not mean it is impossible to destroy groups in these places using displacement. On the contrary, mountainous terrains can exhaust victims faster. Areas that do not have 'vast spaces' but are instead littered with towns and human communities (which may provide escape, shelter, and/or vital human needs) and land masses that are inhospitable to atrocities due to the capabilities of local knowledge, the survivability and availability of resources to meet vital human needs, and areas to hide from perpetrators present challenges to perpetrators that may drive them to select other killing methods. In this sense, a DA crime requires a sizable land mass and may only be possible to implement in countries that have open territories and where the chosen group does not have the survival skills for that particular terrain, for example the United States, Canada, Russia, Central Asian territories, Namibia, Turkey, and other large land masses.

\section{Demographic Density}

Demographically dense countries may be better suited for other types of killing campaigns, notably direct killing campaigns, and DA crimes may not be pragmatically possible. The extremely violent direct killing campaign in Rwanda was in part made possible due to Rwanda's demographic density and the mass mobilization of many individuals and groups in the genocide. In contrast to this societal-wide organized direct killing, DA crimes are perpetrated by comparatively smaller groups of perpetrators and require a longer time to destroy victims. In this way, DA crimes do not necessarily require the consent of the entire polity and does not require coercion into killing, which is conducted away from populated demographic zones.

Forcibly displacing victims in full view of onlookers may create objectors, rescuers, resisters, and others that oppose the perpetrating, but resistance in the face of atrocities can be incredibly

${ }^{39}$ Donald Green and Ian Shapiro, Pathologies of Rational Choice Theory: A Critique of Applications in Political Science (New Haven: Yale University Press, 1996), 1-32. 
difficult, as demonstrated by German resistance efforts against Nazi authorities. ${ }^{40}$ Ultimately, perpetrators may not have their power without the support of the mass public, whether imposed, tangential, or wholehearted as that may be, otherwise they would not require concerted efforts to veil the public nor attempt to homogenize their thoughts. Support for the killing may wane with the intensity of the visual impact of victims marching past - possibly eroding and undermining the support for killing process, a research problem yet to be examined by systemic scholarship. An example of halting killing processes due to public knowledge is the deportation of Aegean Greeks in 1914 and 1915. Greeks were displaced towards Greece and towards the Anatolian heartland, and men were drafted into the amele taburlar (labour battalions), but these deportations stopped at the urging of the Germans ${ }^{41}$ Presumably, the Germans did not want Greece to enter the First World War as a belligerent against the Central Powers. To avoid angering Greece, the deportations of Greeks were stopped and the deportations of Armenians began.

While this episode is telling of the broader implications of genocide in a cross-border sense, it is also telling in that the Ottomans recognized that visibility of their crimes could lead to negative repercussions for them. At the same time, however, Nazis paraded Jews through the streets. This paradox could be the beginning of future research programmes for studies examining the penetration of exterminationist ideologies and their acceptance among the broader polity - and just how much death and destruction civilians are willing to witness before they offer resistance.

\section{Cost-Effectiveness: Time Available Ratio}

An interesting paradox emerges with the cost-effectiveness of a DA. While previously argued that it is superior in conserving resources, it is deficient in the time required for the killing process. For example, it took only a few hours for the German Schutztruppe to destroy thousands of Herero warriors at the Battle of the Waterberg, but years to destroy the many more tens of thousands that fled the scene of the battle into the desert. ${ }^{42}$ In contrast, it only took a few hours, minutes even, for victims to be gassed and cremated at Sobibor and other extermination camps. ${ }^{43}$ It took the Nazis years to kill millions using mainly direct killing methods, but it took years to kill thousands for the German DA perpetrators in GSWA. If materiel is plentiful and time is limited, perpetrators may decide to select direct killing methods over indirect ones due to the longer time requirements of indirect killing. As grotesque as it may be to argue, it takes time for bodies to die but this process is expedited by exposure to elements and exhaustion during displacement. Nonetheless, indirect killing takes time - significantly more than direct killing. The cost-effectiveness may, therefore, be a hindrance to regimes that have resources and can directly kill their victims quickly, as compared to indirect killing.

\section{Cost Effectiveness: Associated Risks Ratio}

Despite the limited number of troops and personnel utilized for a DA, this form of killing could increase the risk of victims overwhelming the perpetrators displacing them. While there are strong aspects of social disruption and control that a coordinated displacement perpetration plan offers, given that there are limited perpetrators compared to victims. Resistance may be made

\footnotetext{
${ }^{40}$ Klemens von Klemperer, German Resistance Against Hitler: The Search for Allies Abroad 1938-1945 (Oxford: Clarendon Press, 1994), 1-18 and Peter Hoffmann, History of the German Resistance 1933-1945, Third Edition (Montreal, Quebec and Kingston: McGill-Queen's Press, 1996), ix-xii.

${ }^{41}$ Taner Akçam, The Young Turks' Crime Against Humanity: The Armenian Genocide and Ethnic Cleansing in the Ottoman Empire, (Princeton: Princeton University Press, 2012), xvii, Taner Akçam, "The Greek Deportations and Massacres of 1913-1914: A Trial Run for the Armenian Genocide," in The Asia Minor Catastrophe and the Ottoman Greek Genocide, ed. George Shirinian (Bloomingdale: The Asia Minor and Pontos Hellenic Research Centre, Inc., 2012), 73-74, and George Th. Mavrogordatos, Stillborn Republic: Social Coalitions and Party Strategies in Greece, 1922-1936 (Los Angeles: University of California Press, 1983), 199.

${ }^{42}$ Isabel V. Hull, Absolute Destruction: Military Culture and the Practices of War in Imperial Germany (Ithaca: Cornell University Press, 2005), 7-55 and Isabel V. Hull, "The Measure of Atrocity: The German War Against the Hereros: The Military Campaign in German Southwest Africa, 1904-1907," GHI Bulletin 37 (2005), 39-43.

${ }^{43}$ Yitzhak Arad, Belzec, Sobibor, Treblinka: The Operation Reinhard Death Camps (Bloomington: Indiana University Press, 1999), 75-80 and 170-180.
} 
possible by the combination of limited perpetrators linked with the wide, open spaces victims are displaced into, creating an especially possible opportunity for victims to overwhelm perpetrators, however slight this chance may be on a sustained basis. Victims may rebel, like the Armenians at Van, may try to formally resist in a large battle, like the Herero at the Waterberg, or may provide concerted nonviolent resistance like the Cherokee. ${ }^{44}$ Despite the eventual defeats in these resistance movements, they still caused logistical and materiel setbacks and problems in executing atrocities.

Victims can pose problems to perpetrators during, before, and after displacement. The Pontic Greek collaboration with Russian forces in the Great War demonstrates one of the risks of intervention and collaboration in displacement atrocities. Despite the vast spaces utilized, logically interventions against the limited number of perpetrators can halt crimes. The few perpetrators utilized cannot withstand a military intervention from either internal or external resistance or forces. The few perpetrators required means less personnel with military-grade materiel; an easier ability for interventions to halt or destroy perpetrator groups due to the simple lack of arms and an asymmetrical balance of hard power. The same can be said of internal resistance. Displacement columns of victims 'escorted' by few perpetrators can be, logically, overwhelmed by a small group of resisters because of this asymmetry.

\section{Stages and Cases: Displacement Atrocities in Practice}

The preceding section has discussed a theory of displacement atrocities. This section offers an examination of five typical stages of DA crimes and applies the developed DA crime theoretical framework to the atrocities inflicted on the Cherokees, Hereros, and Pontic Greeks. Instead of a chronological exploration of each case, this theory testing section draws on previous research into the three atrocities and deconstructs their perpetration within the DA crime theory.

\section{Target Identification}

Populations can be targeted for any multitude of reasons. Gregory Stanton's Ten Stages of Genocide model, and Daniel Feierstein's genocidal social practices model provide useful theoretical beginning marks for understanding the trajectories of genocide and atrocities ${ }^{45}$ In a DA, perpetrators select their targets for any multitude of reasons including, but not limited to, a group's religion, social class, race, ethnicity, nationality, status, political views, or any other unique trait. Identification may be affected by recent historical animosities and/or poor or strained relations with the perpetrator group, however this is comprised. The three cases analysed in this article provide the diverse range of perpetrator reasons for displacing the targeted group, ranging from geographical, political, economic, military, and socio-religious reasons.

The Cherokee Trail of Tears should be understood within the context of colonial genocide in the Americas. This is yet another chapter of colonial forces acting against an indigenous group in order to secure rich and fertile lands, resources, and living spaces. The Cherokees were one of the 'Five Civilized Tribes', a colonial term in reference to the Cherokee, Choctaw, Muscogee (Creek), Chickasaw, and Seminole tribes in the Southern USA. ${ }^{46}$ These tribes wore European clothing, engaged in the US capitalist economy, and willingly shifted their cultural practices to adopt dominant American values. In return for their loyalty, codified in treaties of non-interference, the US government promised that the tribes would remain politically sovereign in specified territories. A major promise was that the tribes would not experience interference by American settlers moving west. ${ }^{47}$ Before the War of 1812 between the Americans and British/Canadians in North

\footnotetext{
${ }^{44}$ Raymond Kévorkian, The Armenian Genocide: A Complete History (London: I.B. Tauris \& Co., 2011), 326-331, Hull, Absolute Destruction, 53-54, and Walter H. Conser, "John Ross and the Cherokee Resistance Campaign," The Journal of Southern History 44, no.2 (1978), 191-205.

${ }^{45}$ Gregory Stanton, “The Ten Stages of Genocide," Genocide Watch, http://www.genocidewatch.org/genocide/ tenstagesofgenocide.html, and Feierstein, "The Concept of 'Genocidal Social Practices'," 18-36.

${ }^{46}$ C.H. Fitch, "The Five Civilized Tribes: Indian Territory," Journal of the American Geographical Society of New York 32, no. 1 (1900), 15 and Robert J. Miller, Native America, Discovered and Conquered: Thomas Jefferson, Lewis Clark, and Manifest Destiny (Westport: Praeger Publishers, 2006), 92.

${ }^{47}$ Miller, 92, Theda Perdue and Michael D. Green, The Cherokee Removal: A Brief History with Documents (New York: Bedford/St. Martin's, 2005), 8-15, and Amy H. Sturgis, The Trail of Tears and Indian Removal (Westport: Greenwood
} 
America, Indigenous communities were believed to be wandering peoples and were entitled to reside in and cultivate their selected lands. After the war, though, Jacksonian Americans believed that Indigenous peoples were squatters on rightful American lands, forming a clear departure from previous conceptualizations of land rights regarding the Five Civilized Tribes. The white settler communities began to encroach on what the tribes believed to be their rightful lands. ${ }^{48}$ The Seminole Wars (1814-1819, 1835-1842, and 1855-1858) and other engagements continued a period of extreme tensions between the US government and the Five Civilized Tribes. ${ }^{49}$

General (later President) Andrew Jackson gained his 'Indian fighter' reputation for his numerous well-documented atrocities against Native Americans during the military campaigns. ${ }^{50}$ His military service informed his political service as Jackson continually exhibited anti-Native American dogmas and racism, believing that the USA would not be safe if it did not eliminate Native American warring capabilities. ${ }^{51}$ The Jacksonian presidency can only be described as laying the legal and social frameworks required for killing and displacing Native Americans. His entire presidential campaign was centred on the promise of 'Indian Removals' and his reputation as an 'Indian fighter'. ${ }^{2}$ To make the removals possible, he persuaded the US legislative branches to pass the Indian Removal Act (1830) ('the Act'), which allowed the President to directly negotiate removals with individual Native American tribes. ${ }^{53}$ A central component of the Act was designed to forcibly remove all Native Americans in the path of westward expansion; when tribes refused to leave, Jackson became increasingly repressive and forceful. This was quite evident against the Cherokees who did not want to leave their territory among the borders of Georgia, Alabama, Tennessee, and the Carolinas. ${ }^{54}$

When American settlers began intruding on Cherokee lands, part of a larger discursive conceptualization of European/American colonization and expansionist policies, the State of Georgia passed laws eroding Cherokee sovereignty over their territory, requiring all whites in the Cherokee Indian Territory to obtain a licence to live there, contravening previous treaties that granted Cherokee sovereignty. ${ }^{55}$ Samuel Worcester, Elizur Butler, and nine other white missionaries refused to obtain this licence and were sentenced by Georgia state law, which was eventually overturned in the Supreme Court by Chief Justice John Marshall, who asserted Cherokee rights over Cherokee lands. Jackson, however, manoeuvred around this. ${ }^{56}$

Jackson's administration negotiated with a fringe Cherokee Treaty Party, an illegitimate political party that did not represent the majority Cherokee voices that resisted removal (at least 15,665 individuals). The Treaty Party travelled first to Washington, D.C. and then to New Echota where they signed the Treaty of New Echota, the document used to legally justify Cherokee displacement. It was ratified by a single Senate vote on 17 May 1836, requiring that the Cherokees had until 1838 to move west of the Mississippi River. Jackson's goal of Indian removal had finally been completed in theory; all that was left to do was to deport the Cherokees in the successive Presidency of Martin Van Buren..$^{57}$ The discovery of gold on Cherokee lands was a major

Press, 2007), 33.

${ }^{48}$ Gary Clayton Anderson, Ethnic Cleansing and the Indian: The Crime That Should Haunt America (Norman: University of Oklahoma Press, 2014), 112.

${ }^{49}$ John Missall and Mary Lou Missall, The Seminole Wars: America's Longest Indian Conflict (Jacksonville: University of Florida Press, 2004) and Brent R. Weisman, "Nativism, Resistance, and Ethnogenesis of the Florida Seminole Indian Identity," Historical Archaeology 41, no. 4 (2007), 198-202.

${ }^{50}$ F.P. Prucha, “Jackson's Indian Policy: A Reassessment," The Journal of American History 56, no. 3 (1969), 527 and $537-539$.

${ }^{51}$ Ibid., 537-539.

${ }^{52}$ Perdue and Green, The Cherokee Removal, 15-19 and Sturgis, The Trail of Tears, 37.

${ }^{53}$ United States Congress, Indian Removal Act, Twenty-First Congress, Sess. 1, Ch. 148, Library of Congress, 28 May 1830.

${ }^{54}$ Sturgis, The Trail of Tears, 59.

${ }^{55}$ Perdue and Green, The Cherokee Removal, 79-80, William G. McLoughlin, Champions of the Cherokees: Evan and John B. Jones (Princeton: Princeton University Press, 1990), 136, and Grace Steele Woodward, The Cherokees (Norman: University of Oklahoma Press, 1963), 201.

${ }^{56}$ Worcester v. Georgia, 31 U.S. 515 (1832).

${ }^{57}$ Ehle, Trail of Tears, 222-226 and Perdue and Green, The Cherokee Removal, 101-103. 
precipitating factor for removal so white Americas could mine and reap the rewards of former Cherokee lands. ${ }^{58}$

Similarly, Herero-German relations are that of an indigenous group facing rapidly shifting policies of their colonizers. The story of the Herero Genocide begins with Adolf Lüderitz's establishment of a permanent German settlement in GSWA in 1884 at Angra Pequena (Portuguese for "small cove"), naming his city Lüderitz. ${ }^{59}$ This settlement was used as the launching point of racist and Social Darwinist German colonial attitudes towards the Herero and other groups residing within GSWA, with missionaries hoping to Christianize the local populations. ${ }^{60}$ Aside from these broad social attitudes, there are four reasons why the Herero were killed.

The first is Samuel Maharero, the Chief of the Hereros. He worked with German Governor Theodor Leutwein to centralize power to himself, marginalizing powerful oppositional Herero voices and leaders in the shift of power to Maharero. While he did lead the Hereros in revolt in 1904, Maharero acquiesced to Leutwein's demands which led to limited formal Herero objections to German policies, paving the way for the atrocities of 1904-1908. ${ }^{61}$ Second, the Germans desired a railway network connecting their major mining assets in the interior of GSWA and the colonial coastline cities to make resource extraction far easier. However, the railways ran directly through Hereroland meaning the land had to be taken initially by treaty, and eventually by force. The Hereros were used as slave labourers during the genocide to complete the lines by $1908 .{ }^{62}$ German theft of land for the railroads, and colonial practices in general, were conducted by crafting treaties which were misinterpreted by the Hereros as temporary loans of the land, not permanent acquisitions. By the time that the Herero realized the land would not be returned to their possession, there was little they could do because the Germans had brought more settlers and weapons to GSWA. ${ }^{63}$ From 1894 to 1904, German colonials began a period of increasing military and bureaucratic control over captured lands, rejecting any and all Herero claims to the land.

Third, with their livelihoods diminished due to the lost lands, the Hereros had to take out loans at exorbitant rates from the Germans that were virtually unrepayable. ${ }^{64}$ The Herero had no choice but to accept these percentages because their lifestyle and income had been disrupted by German land theft. When the Hereros could not repay the loans, GSWA was thrown into an economic crisis, 'solved' by well-intentioned but misguided legislation from Leutwein mandating that on 1 November 1903 all loans would be eliminated with no reimbursement by the German government. In reaction, German colonials recalled their loans in different ways, most notably by forcing the Herero to pay for the lost money with cattle and other livestock. ${ }^{65}$ These animals were critical to the Herero's existence, but were desired by Germans who wanted to fill their newly-acquired lands with livestock. Herero income and livelihood were threatened and on the brink of collapse. A rinderpest outbreak among Herero cattle exacerbated the loss of traditional forms of income

${ }^{58}$ Ehle, Trail of Tears, 222-226 and Perdue and Green, The Cherokee Removal, 101-103.

${ }^{59}$ Jan-Bart Gewald, Herero Heroes: A Socio-Political History of the Herero of Namibia 1890-1923 (Athens: Ohio University Press, 1999), 3-6 and Jeremy Sarkin, Germany's Genocide of the Herero: Kaiser Wilhelm II, His General, His Settlers, His Soldiers (Cape Town: UCT Press, 2011), 16.

${ }^{60}$ Sarkin, Germany's Genocide of the Herero, 16, 62, 78, 89, 91, 96, 131, 140, and 236.

${ }^{61}$ Gewald, Herero Heroes, 61, 87, and 102-109, Jon M. Bridgman, The Revolt of the Hereros (Los Angeles: University of California Press, 1981), 59 and 68, and Drechsler, 'Let Us Die Fighting', 84-88.

${ }^{62}$ Sarkin, Germany's Genocide of the Herero, 123-124 and Jürgen Zimmerer, "War, Concentration Camps and Genocide in South-West Africa: The First German Genocide," in Genocide in German South-West Africa: The Colonial War (1904-1908) in Namibia and its Aftermath, eds. Jürgen Zimmerer and Joachim Zeller, trans. Edward Neather (Monmouth: The Merlin Press Ltd., 2008), 20.

${ }^{63}$ Sarkin, Germany's Genocide of the Herero, 67, Drechsler, 'Let Us Die Fighting', 11-114, Jürgen Zimmerer, "The Model Colony? Racial Segregation, Forced Labour, and Total Control in German South-West Africa," in Genocide in German South-West Africa: The Colonial War (1904-1908) in Namibia and its Aftermath, eds. Jürgen Zimmerer and Joachim Zeller, trans. Edward Neather (Monmouth: The Merlin Press Ltd, 2008), 27, and Zimmerer, "War, Concentration Camps and Genocide in South-West Africa."

${ }^{64}$ J.H. Wellington, South West Africa and its Human Issues (Oxford: Clarendon Press, 1967), 190-191 and Bridgman, The Revolt of the Hereros, 59.

${ }^{65}$ Wellington, South West Africa and its Human Issues,190-191, Bridgman, The Revolt of the Hereros, 59, and Drechsler, 'Let Us Die Fighting', 118-119. 
and forced the Herero to work as labourers for German colonials on the railroad which, ironically, would then resupply and transport German troops that perpetrated the genocide. In addition, it totally broke all forms of traditional Herero socio-political systems, forcing them to work within dictated German frameworks. At this point, Hereros were near-fully subjugated within the German colonial system as subjects. ${ }^{66}$

Finally, it was the German interest in creating Herero reserves which intended to segregate the Herero. However, the plans were rejected by German colonials as they believed the lands for the Herero were too greats. ${ }^{67}$ The Herero, quite obviously, reacted negatively towards the idea of being shuttled to reserves. While Maharero had acquiesced to previous German commands, he and the Hereros finally rose up against colonial domination, leading to Maharero's finest quote, "let us die fighting." 68

The Pontic Greeks, in one of the most layered and intricate steps toward atrocities, were killed for a multitude of complex factors. The Pontic Greeks were situated along the southern Black Sea coastline and contributed many Greek legends, philosophical and scholarly works, and have one of the oldest cultures in the western hemisphere. ${ }^{69}$ Turks from the Turkmen region of Central Asia began to emigrate to Pontus and the general modern-day Turkey region in the $11^{\text {th }}$ Century. ${ }^{70}$ This gradual process of demographic change marked the beginning of Turks becoming the majority group in the region. The two groups thrived under the Byzantine Empire and survived its decline, only to witness the rise of the Ottoman Empire after the conquests of Osman Gazi (Osman I) in $1281 .^{71}$ The Ottoman Empire dominated the Middle East and Southern Europe and lasted from Mehmed II's conquests against the Byzantine Empire to the rise of Mustafa Kemal's (Atatürk) nationalist drive in 1923, forming modern-day Turkey. The Empire, for the Pontic Greeks and other Christian minorities, was repressive politically, economically, and socially. The proliferation of Islam throughout the Ottoman Empire caused rifts between believers in Islam and 'gavurs' (a pejorative term for infidels, non-believer Christians). ${ }^{72}$ Religious difference between the Christian Pontians and Muslim Turks was a backdrop that informed Ottoman reactions to short-term crises causing the genocide, but it does not explain the broader Ottoman Genocide of Christian Minorities (Armenians, Greeks, and Assyrians, 1912-1925) of which the Pontians were victims from 1916-1918 and 1919-1923. ${ }^{73}$ In all, 353,000 Pontians were killed as part of the approximately 2.5 million Christians in total (primarily 1,500,000 Armenians; 750,000 Greeks; and 250,000 Assyrians). ${ }^{74}$ Religious difference may have been a necessary variable for the types of violence employed against the Pontic Greeks, but it is certainly not a sufficient variable in explaining why they were targeted and killed.

Christian minorities were persecuted based on their perceived injustices against Muslim Turks. These ideas are contextually placed within the declining Ottoman Empire which was being scapegoated on 'scheming' Christian populations. ${ }^{75}$ Christians were never given full and equal rights in the Ottoman Empire as their Muslim counterparts. Despite the Tanzimat Reforms (1839 to 1876) designed to equalize Christians and Muslims, among a number of other goals, few reforms were implemented and a civil rights disparity was ever-present in pre-genocide Ottoman

\footnotetext{
${ }^{66}$ Gewald, Herero Heroes, 130-140.

${ }^{67}$ Drechsler, 'Let Us Die Fighting', 114-116 and Bridgman, The Revolts of the Hereros, 57-58.

${ }^{68}$ Drechsler, 'Let Us Die Fighting', i.

${ }^{69}$ Thea Halo, Not Even My Name: A True Story (New York: Picador, 2001), 39-40.

${ }^{70}$ Christos Papoutsy, Ships of Mercy: The True Story of the Rescue of the Greeks: Smyrna, September 1922 (Portsmouth: Peter E. Randall Publisher LLC, 2008), x-xi.

${ }^{71}$ Andrew Mango, Atatürk: The Biography of the Founder of Modern Turkey (New York: The Overlook Press, 1999$), 4$.

${ }^{72}$ Hofmann, "Cumulative Genocide," 84.

${ }^{73}$ Taner Akçam, A Shameful Act: The Armenian Genocide and the Question of Turkish Responsibility (New York: Henry Holy and Company, LLC, 2006), 109-204, Peter Balakian, The Burning Tigris: The Armenian Genocide and America's Response (New York: HarperCollins, 2003), 35-62 and 103-196, and Hofmann, "Cumulative Genocide," 39.

${ }^{74}$ Hofmann, "Cumulative Genocide," 106 and Adam Jones, Genocide: A Comprehensive Introduction, Second Edition (New York: Routledge, 2011), 150-151.

${ }^{75}$ Naimark, Fires of Hatred, 26-32 and Erick J. Zürcher, The Young Turk Legacy and Nation Building: From the Ottoman Empire to Atatürk's Turkey (New York: I.B. Tauris \& Co Ltd., 2010), 49-150.
} 
territories. Christians did not have equal legal, political, economic, or social rights and were considered outcasts of the Empire which adopted Islam as an official religion. ${ }^{76}$

Economically, Christians were largely ostracized from the traditional Ottoman economy of agriculture and subsistence-level business, but thrived in the positions they were forced into: professional employment, banking, small business ownership, and trade and commerce. The backward, agrarian economy had to be modernized if the Empire was to thrive in the contemporary world and compete with the Great Powers of the $19^{\text {th }}$ and early $20^{\text {th }}$ Century Europe. To modernize, the Sultan recruited western advisers to transform the Ottoman economy. The areas which were to be expanded were positions to which Christians had been ironically ostracized previously. ${ }^{77}$ To the Turks, this appeared to be thinly-veiled 'Christians helping Christians' to undermine the Empire. Ironically, to fund these modernization projects, the Sultan had to borrow from the very nations from which the advisors came: Christian European countries. The loans from these countries to the Empire became so large that at one point, over 90 percent of the Ottoman banking system was controlled by western countries, mostly Britain and France. ${ }^{78}$ This severely handicapped Ottoman citizens' abilities to secure loans and gave the appearance of high-level economic and political control of the predominantly Muslim Empire by Christians both internally and externally.

The Christian wars of independence in the Balkans and Southeastern Europe, areas of Ottoman holding, solidified the idea that Christians wanted to undermine the Empire's existence so they could have their own state(s). Not wanting to see more countries separate after Bulgaria, Greece, Montenegro, and Serbia achieved independence from 1912-1913, Ottoman citizens began to believe that Christian minorities could truly not be trusted. ${ }^{79}$

The combination of these socioeconomic and political factors made Ottoman citizens desire change, which arrived in the form of the Young Turk (YT) revolution. Originally targeted to Pan-Ottomanism, conceptualizing all citizens as equals, this policy shifted to Pan-Turkism, and Christian minorities were targeted in revolutionary scapegoating, exploiting the previous systemic repressions, deprivations, and negative attitudes..$^{80}$ The killing processes began in 1912 and did not end until 1925, encompassing both the revolutionary YT regime and the regime of Mustafa Kemal (Atatürk). A main justification offered by perpetrators was not religious difference itself, but that Christians in the Empire's interior might try to undermine the Empire so they could separate. In order to stop this, the two regimes instituted genocidal policies.

\section{Elimination of Resistance}

As with the previous section demonstrating the diversity of reasons populations are targeted, this section on eliminating target group resistance will elucidate the different types of resistancecrushing opportunities to make displacement possible. Resistance can be eliminated in many ways, including legislated pacification and violence, destruction in battle, or raids targeting communities.

The Cherokees were disarmed by legislated removal processes which were enacted by the US military. Jackson ordered the disarming of the Cherokee Nation as early as 1836 and this policy

\footnotetext{
${ }^{76}$ Akçam, A Shameful Act, 32 and Ronald Grigor Suny, "Writing Genocide: The Fate of the Ottoman Armenians," in $A$ Question of Genocide: Armenians and Turks at the End of the Ottoman Empire, eds. Ronald Grigor Suny, et al. (New York: Oxford University Press, 2011), 33.

${ }^{77}$ Rouben Paul Adalian, "The Armenian Genocide," in Century of Genocide: Critical Essays and Eyewitness Accounts, Fourth Edition, eds. Samuel Totten and William S. Parsons (New York: Routledge, 2013), 55, Walter F. Weiker, "The Ottoman Bureaucracy: Modernization and Reform," Administrative Science Quarterly 13, no. 3 (1968), 452 and 469-470, Donald Quataert, "Labor History and the Ottoman Empire, c. 1700-1922," International Labor and Working-Class History 60 (2001), 98-105, Erick J. Zürcher, Turkey: A Modern History, Revised Edition (New York: I.B. Tauris, 2004), 85, and HansLukas Kieser, Nearest East: American Millennialism and Mission to the Middle East (Philadelphia: Temple University Press, 2010), 76-77.

${ }^{78}$ Balakian, The Burning Tigris, 35-36 and Akçam, A Shameful Act, 19-27 and 100.

${ }^{79}$ John Mourelos, "The Persecutions in Thrace and Ionia in 1914 and the First Attempt at an Exchange of Minorities between Greece and Turkey," in The Genocide of the Ottoman Greeks: Studies on the State-Sponsored Campaign of Extermination of the Christians of Asia Minor (1912-1922) and Its Aftermath: History, Law, Memory, eds. Tessa Hofmann, et al. (Sarsdale: Melissa International Ltd, 2011), 114 and Hannibal Travis, “'Native Christians Massacred': The Ottoman Genocide of the Assyrians during World War I," Genocide Studies and Prevention 1, no. 3 (2006), 327-328.

${ }^{80}$ Jones, Genocide, 151-153.
} 
was initially carried out by General John Ellis Wool, though he was relieved of his command due to his stated personal connections with the Cherokees and the charge, for which he was later exonerated, that he requisitioned American property to aid the Cherokees. ${ }^{81}$ General Winfried Scott assumed command and from 1836-1838, American troops swept through Cherokee communities confiscating weaponry that could have been used to fight displacement even though Cherokee Chief John Ross did not intend resistance. A number of documented shootings and executions demonstrate that the disarming process was not always peaceful, as Scott supposedly intended. ${ }^{82}$

In a much different fashion, the Herero rebellion, and almost all resistance opportunities, were crushed at the Battle of the Waterberg (11 August 1904). Lothar von Trotha had been sent to GSWA from Germany with a fresh contingent of Schutztruppe to defeat the Herero, now in full rebellion. In the days preceding the battle, von Trotha expressed his desire to "annihilate," or at least expel, the Hereros from GSWA..$^{83}$ The Herero brought 6,000 predominantly male warriors to the battle but the Germans, much more well-equipped with artillery and machine guns, were easily able to defeat the Herero, who suffered casualties in the thousands compared to Germany's 45 casualties. ${ }^{84}$ Von Trotha desired the destruction of the Herero at the Waterberg entirely, but when he was unable to surround the other 50,000-60,000 Hereros in the vicinity of the battle, he chose to forcibly displace them into the inhospitable desert. ${ }^{85}$ After this battle, the Herero warrior class were effectively neutralized, key military materiel was destroyed or captured, and the Herero could not offer effective resistance after this event.

The Pontic Greeks suffered similar gendered genocide (gendercidal) policy outcomes. ${ }^{86}$ The brutal amele taburları were organized and Pontian men were sent there to be slave labourers for the Ottoman Army. ${ }^{87}$ In this sense, the YT and later Kemalist regimes solved two problems at once: they were able to move military materiel and were able to do so by killing Pontian men by indirect means (working them to death) which eliminated a significant portion of the population able to resist genocide..$^{88}$ This is not to say females were not offering resistance, but in the context of traditional resistance, males were more active participants. The elimination of fighting-age Pontian men was of central importance to the genocidal plans as this gendercidal segregation and killing helped make the later deportation columns from Pontus to Der Zor possible as they were devoid of resistance fighters.

\section{Social Disruption}

As previously explored, one of the major reasons that perpetrators select displacement as a method of atrocity is due to the social disruption and confusion that displacement causes among victims, making the process much easier to perpetrate. Disruption in all cases meant the bypassing, exclusion/ isolation, or killing of target group leadership. The legitimate Cherokee leadership was excluded by circumventing the true representatives of the Cherokee nation. Legitimate representatives

\footnotetext{
${ }^{81}$ Woodward, The Cherokees, 193 and Vicki Rozema, Voices from the Trail of Tears (Winston-Salem: John F. Blair, Publisher, 2003), 65-69.

82 Thurman Wilkins, Cherokee Tragedy: The Story of the Ride Family and the Decimation of a People (London: Collier Macmillan Ltd, 1970), 309, Woodward, The Cherokees, 205, Sturgis, The Trail of Tears, 57-59, and Russell Thornton, "Cherokee Population Losses during the Trail of Tears: A New Perspective and a New Estimate," Ethnohistory 31, no. 4 (1984), 292.

${ }^{83}$ Gewald, Herero Heroes, 173.

${ }^{84}$ Sarkin, Germany's Genocide of the Herero, 38-39, Bridgman, The Revolt of the Hereros, 112-113 and 124, Drechsler, 'Let Us Die Fighting', 155-156, and Jon M. Bridgman and Leslie J. Worley, "Genocide of the Hereros," in Century of Genocide: Critical Essays and Eyewitness Accounts, Third Edition, eds. Samuel Totten and William S. Parsons (New York: Routledge, 2009), 27.

${ }^{85}$ Drechsler, 'Let Us Die Fighting', 161-163 and Zimmerer, "War, Concentration Camps and Genocide in South-West Africa," 47.

${ }^{86}$ Adam Jones, "Gendercide and Genocide," Journal of Genocide Research 2, no.2 (2000), 185-191 and Helen Fein, "Genocide and Gender: The Uses of Women and Group Destiny," Journal of Genocide Research 1, no. 1 (1999), 43-46.

${ }^{87}$ Erick J. Zürcher, “Ottoman Labour Battalions in World War I," in The Armenian Genocide and the Shoah, eds. Hans-Lukas Kieser and Dominik J. Schaller (Zürich: Chronos-Verlag, 2002), 187-194.

${ }^{88}$ Ibid.
} 
were silenced and excluded by undue legislative processes. ${ }^{89}$ The diversity in Herero leadership was mostly silenced before the genocide with the centralization of power with Maharero, but the Battle of the Waterberg caused many more deaths among leadership, leaving the Herero with few individuals to quickly organize either escape or resistance..$^{90}$ Like the Herero, direct deaths were used by the YT and Kemalist regimes to quickly kill Pontic Greek leadership. As early as 1909 and 1911, Greek leadership in the Ottoman Empire was being destroyed. Politically, Greeks were completely segregated from the YT (previously Young Ottoman) revolutionary organization and government primarily after the 1913 internal coup that led to the rise of the YT, consisting of Mehmed Talaat, Ismail Enver, and Admed Djemal - the 'Three Pashas' or the 'Triumvirate'. ${ }^{91}$

\section{Initial Displacement Operations}

The three previous stages of DA crimes culminate in the initial displacements of the populations. These can take multiple forms but this is the stage where perpetrators institute their plans fully. These initial operations are typically where the bulk of the direct killing occurs. The sustained displacement operations which follow are where the primarily indirect killings take place.

The initial Cherokee displacements occurred in Spring 1838 when the Cherokee were displaced to the forts (concentration camps) that Scott's infantry had constructed for the operations. In these forts, approximately 1,000 Cherokees died by hunger or disease. A small number of Cherokees resisted but they were subdued by US forces. ${ }^{92}$ The initial plan to use river systems to transport the Cherokees was set aside after it proved to be too costly and logistically difficult. It should be noted, though, that four voluntary caravans left before the later forced removals. The first caravans experienced 21 deaths out of an approximate total of 1,681 persons displaced..$^{93}$ Three forced military-guided deportations experienced much higher death rates, with operations spanning from June to September. It is estimated that there were hundreds of deaths (the precise number is uncertain) out of 2,698 deportees. ${ }^{94}$

The later forced removal caravans were the ones that experienced the highest death tolls. The government elected to displace the Cherokees in caravans of approximately 700 to 1,700 persons each overland from Tennessee, to Illinois, to the Indian Territories (in Oklahoma). ${ }^{95}$ The Cherokees were promised enough resources and funds to make their way to the Indian Territories, but resources were rarely available or provided and the funds were insufficient to cover the cost of 16,000 deportees. ${ }^{96}$ The deportation caravans were pushed forward by soldiers at first, but were eventually taken over by Chief Ross to reduce the harm that was being done to the Cherokees due to mismanagement, neglect, or intentional maltreatment. ${ }^{97}$ Above all, the USA was responsible for the Cherokees killed during what became known as the Trail of Tears.

The Battle of the Waterberg was initially intended to destroy all Hereros in the vicinity of the skirmish, but when the Hereros escaped, the Germans shifted their strategy to displacement into the desert. The Schutztruppe under von Trotha began to force the Hereros deeper into the desert and the Hereros began dying at extraordinary rates - one estimate of perhaps 30,000 in the first three weeks in the desert. ${ }^{98}$ When the Germans came upon Hereros who had fallen or were stragglers from the main group, they would either kill them immediately or send them to the extermination/ work camp on Shark Island.${ }^{99}$ Others were left to die in the sand and some others were assigned to

\footnotetext{
${ }^{89}$ Sturgis, The Trail of Tears, 48-49.

${ }^{90}$ Gewald, Herero Heroes, 61, 87, and 102-109, Bridgman, The Revolt of the Hereros, 59 and 68, and Drechsler, 'Let Us Die Fighting', 84-88.

${ }^{91}$ Adalian, "The Armenian Genocide", 114.

${ }^{92}$ Woodward, The Cherokees, 194 and Sturgis, The Trail of Tears, 58.

${ }^{93}$ Rozema, Voices from the Trail of Tears, 189.

${ }^{94}$ Ibid.

${ }^{95}$ Sturgis, The Trail of Tears, 59.

${ }^{96}$ Ibid and Woodward, The Cherokees, 208-212.

${ }^{97}$ McLoughlin, Champions of the Cherokees, 182 and Woodward, The Cherokees, 205-208.

${ }^{98}$ Kiernan, Blood and Soil, 383-384.

${ }^{99}$ Ibid., Casper Wulff Erichsen, "Forced Labour in the Concentration Camp on Shark Island," in Genocide in German South-
} 
be slave labourers to work on the unfinished railroads. ${ }^{100}$ The initial battle led to displacement and though the initial plans did not call for this, the Germans adapted to the changed strategic situation they encountered; with the Hereros already fleeing into the desert, the Germans fluidly altered their plans for the annihilation of the Herero people. ${ }^{101}$

The YT and Kemalist regimes did not have the same kind of intense battle as the Germans did with the Hereros, though there were small skirmishes and battles, most notably at Musa Dagh with the Armenians. ${ }^{102}$ Instead, Pontic Greek men (aged 18-48) were forcibly conscripted into the amele taburlarn and died in great numbers, sometimes upwards of 90 percent. ${ }^{103}$ Beginning in the countryside and later urban areas, the Turks raided Pontic Greek homesteads and initiated the deportation caravan process. The Turks marched the remaining Pontic Greeks towards Der Zor in caravans, and they experienced death rates of approximately 80 to 90 percent. These caravans were 'escorted' by the Teşkilât-ı Mahsusa (Special Organization) or Çetes (organized brigands), and were harassed by these two groups throughout the operations. ${ }^{104}$ The killing of Pontic Greeks came in waves as they were first deported from rural centres, then from urban centres, over a number of years, into the desert. This has lead Hofmann to argue that the entirety of the Greeks' spatial and temporal atrocity victimhood experiences amounts to a cumulative genocide. ${ }^{105}$

\section{Sustained Displacement Operations}

With the Cherokees displaced, the American government failed in all respects to deliver resources and funds required to complete the displacement safely, meaning that the American government bears responsibility for the neglected promises and for the deaths associated with the Trail of Tears (the Cherokees would not have moved themselves if not for American edicts). The thirteen Cherokee caravans were sent from 23 August to 5 December 1838, arriving in the new Indian Territories from 4 January to 24 March $1839 .{ }^{106}$ These departure and arrival dates necessarily mean that there was no possible way for the Cherokees to survive winter with the material assistance, or lack thereof, they were provided. ${ }^{107}$ The Cherokees had to march from Tennessee to Illinois to Oklahoma guided entirely on their own, save for a select few white missionaries accompanying the caravans. Since there was no escape for the Cherokees, who already intended no military resistance, American military involvement during displacement appears unnecessary. According to one estimate by Russell Thornton, of 16,000 Cherokees displaced, at least 4,000 died along the Trail of Tears, and at least another 4,000 died within the first few weeks and months in the Indian Territory due to the deprivations suffered during the displacement. These figures show that approximately 8,000 Cherokees or 50 percent of the population, died during the Trail of Tears. ${ }^{108}$ Other estimates place the death toll at 4,000, around 25 percent of the Cherokee population. ${ }^{109}$ Another recent estimate

West Africa: The Colonial War (1904-1908) in Namibia and its Aftermath, eds. Jürgen Zimmerer and Joachim Zeller, trans. Edward Neather (Monmouth: The Merlin Press Ltd, 2008), 85, and Drechsler, 'Let Us Die Fighting', 150 and 207.

${ }^{100}$ Gewald, Herero Heroes, 186-188.

${ }^{101}$ Ibid, 173.

${ }^{102}$ Michael Bobelian, Children of Armenia: A Forgotten Genocide and the Century-Long Struggle for Justice (New York: Simon \& Schuster, 2012), 82-85 and Franz Werfel, The Forty Days of Musa Dagh, trans. Geoffrey Dunlop and James Reidel (New York: Caroll \& Graf, 2012), vii-xvii.

${ }^{103}$ Stavros T. Stavridis, "International Red Cross: A Mission to Nowhere," in The Genocide of the Ottoman Greeks: Studies on the State-Sponsored Campaign of Extermination of the Christians of Asia Minor (1912-1922) and Its Aftermath: History, Law, Memory, eds. Tessa Hofmann, et al. (Sarsdale: Melissa International Ltd, 2011), 278, Hofmann, "Cumulative Genocide," 64 and 74, and Akçam, The Young Turks' Crimes Against Humanity, 95-96.

${ }^{104}$ Hofmann, “Cumulative Genocide," 57 and 102.

${ }^{105}$ Ibid.

${ }^{106}$ Rozema, Voices From the Trail of Tears, 189 and United States Department of the Interior, National Register of Historic Places, Multiple Documentation Form: Historic and Historical Archaeological Resources of the Cherokee Trail of Tears, OMB No.1024-0018 (1992).

${ }^{107}$ Sturgis, The Trail of Tears, 59 and Woodward, The Cherokees, 208-212.

${ }^{108}$ Thornton, "Cherokee Population Losses during the Trail of Tears," 289-298.

${ }^{109}$ James Mooney, Historical Sketch of the Cherokee (New Brunswick: Transaction Publishers, 2009), 127. 
by Gary Clayton Anderson is 1,000 deaths during incarceration in the camps and 2,000 deaths along the Trail of Tears and upon immediate arrival in Oklahoma. ${ }^{110}$ Thus, while exact figures are impossible to confirm, it is estimated that anywhere between 3,000 and 8,000 Cherokees died. While Ross went to St. Louis to get supplies in early 1839, many Cherokees had already died and were dying due to exposure, starvation, and disease. ${ }^{111}$ The initial deportation aim of 70 days was expanded to 120 days as Cherokee caravans began to reach the Indian Territory in January 1839, but the majority did not arrive until spring 1839. ${ }^{112}$ By poor execution of the displacement and neglect of human beings at least, and certainly as a part of the colonial genocide process over 400 years in North America, the US government was responsible for the deaths of up to half the Cherokees it deported from their homelands.

German forces had a different plan of perpetration. Instead of escorted caravans of deportees, the Germans guarded the borders of the deserts so the Herero could not escape the deserts. In this death trap, the Germans also guarded water wells so when the victims attempted to gain access to these, they were shot at and driven away. If they were undefended, the wells were poisoned by the Germans. ${ }^{113}$ There were many cases of Hereros digging for water only to find more sand and no water. After killing their few remaining cattle for food, the Hereros quickly died in the desert when resources were depleted. Of the 50,000 or 60,000 displaced to the desert, only 3,000 escaped to neighbouring countries safely. ${ }^{114}$ Of the 17,000 Hereros sent to labour camps, 6,000 had died by $1907 .{ }^{115}$ This was a quintessential genocide by displacement with killing by primarily indirect methods. As Isabel Hull writes, "most Herero died of thirst, not shooting, and it was the act of pursuit itself more than its manner that led to mass death."116

The Pontic Greek caravans were subjected to levels of brutality that match what was done to the Armenians, well documented by a number of penetrating studies of the genocide. ${ }^{117}$ The Teşkilât-ı Mahsusa and Çetes subjected the Pontic Greeks to physical, mental and sexual abuse, and humiliation during the displacements. When the escorts desired, they beat victims, sometimes committing massacres though direct killings. The caravans were directed across the Turkish heartlands and death was nearly guaranteed. ${ }^{118}$ The perpetrators utilized very few escorts to direct the caravans south, a vital element of this genocide since the wartime restrictions on personnel and materiel placed strains on the forces available for killing operations. From 1916-1918 and 1919-1923, the Pontic Greeks were destroyed by these death caravans through the harsh Turkish heartland and eventually the Syrian Desert. A correlation in the Ottoman Genocide of Christian Minorities is that killing processes were instituted against Christian minority populations in connection with oncoming invasion efforts of Entente campaigns (the Russian invasion from the North and the British Mesopotamian front in the South). The presence of war fronts may have been a precipitating factor in the decision to kill potential revolutionary or Christian populations who could have been 'liberated' by other Christians invading, as perceived by the Turks. In all, 353,000 Pontic Greeks were killed and the other 347,000 were deported to Greece

\footnotetext{
${ }^{110}$ Anderson, Ethnic Cleansing and the Indian, 170.

${ }^{111}$ Wilkins, Cherokee Tragedy, 311-313.

112 Thornton, "Cherokee Population Losses during the Trail of Tears," 289-298, Kenny A. Franks, Stand Watie and the Agony of the Cherokee Nation (Memphis: Memphis State University Press, 1979), 56-57, 64-67, and 94-104, and Ehle, Trail of Tears, 355.

${ }^{113}$ Sarkin, Germany's Genocide of the Herero, 115 and Hull, Absolute Destruction, 53-54.

${ }^{114}$ Bridgman and Worley, "Genocide of the Hereros," 32.

${ }^{115}$ Kiernan, Blood and Soil, 385.

${ }^{116}$ Hull, "The Measure of Atrocity," 42.

${ }^{117}$ Akçam, The Young Turks' Crimes Against Humanity, Akçam, A Shameful Act, Balakian, The Burning Tigris, 265 and 286, and Hannibal Travis, Genocide in the Middle East: The Ottoman Empire, Iraq, and Sudan (Durham: Carolina Academic Press, 2010), 248 and 289-292.

${ }^{118}$ Halo, Not Even My Name, 64-76, Akçam, “The Greek Deportations and Massacres of 1913-1914," 73-74 and 86-87, and Matthias Bjørnlund, "The Persecution of Greeks and Armenians in Smyrna, 1914-1916: A Special Case in the Course of the Late Ottoman Genocides," in The Asia Minor Catastophe and the Ottoman Greek Genocide, eds. George Shirinian (Bloomingdale: The Asia Minor and Pontos Hellenic Research Centre, Inc., 2012), 93 and 101.
} 
in the Greco-Turkish population transfers of $1923 .{ }^{119}$ After genocide, forced conversions and population cleansing, Turkey was almost entirely homogenized and no longer had major Christian minority populations within its borders. Much like the United States of America and Namibia, modern-day Turkey finds its foundational socio-political pillars in atrocity perpetration and victimization.

\section{Displacing and Killing Populations}

These three atrocities offer a diverse range of case-specific traits. The same DA crime was perpetrated on three continents, at three different times, by three different regimes, against three different targets, and by a number of similar and tailored methods to the goals of killing operations. What is similar, however, is the perpetrating regimes' exploitation of large territories, systemic deprivations of vital human needs, primarily indirect killing methods, and limited perpetrators, among the many other similarities explored above, to displace and kill targeted populations as the perpetrators conceptualized them. Certainly there are more cases involving forced displacement and the promise of expanding research into DA crimes to those other cases may help understand systemic perpetration and killing methods even further.

\section{Concluding Remarks}

This article began by asking how and why do perpetrators utilize displacement as a tool to commit atrocities? To answer this, a definition of a DA crime was initially offered, followed by a theoretical construction of the term and its relevant concepts; a logical exploration of why DA crimes may or may not be selected as the method of killing; and a final examination of the five stages of DA crimes applied to three different historical cases: the Cherokees, Hereros, and Pontic Greeks. The purpose of creating a DA crime theory is to highlight the particular style of atrocity perpetration utilizing displacement and primarily indirect killing methods and to demonstrate the need to incorporate this style of killing as a crime in international law. The conceptual exploration expands the knowledge and understanding of why forced deaths occur and adds to a base of understanding atrocities more generally. The DA concept may be particularly useful in understanding the modern internally-displaced person (IDP) phenomenon, especially if there is killing involved and large territories where crimes are perpetrated.

Atrocities are clearly not always prevented and if some form of intervention is undertaken to stop rights violations, it is critical to understand what killing processes are actually being utilized. If these are known, it is easier to understand how to halt flagrant human rights violations militarily and diplomatically, using a plethora of targeted hard and soft power tactics under a broad strategy of undermining perpetration efforts. It is important to theorize about how perpetrators may exploit different sociopolitical situations, geography, and available resources to create machineries of death in order to understand killing processes themselves and to create strategies to prevent, halt, and punish rights violations.

The most important element of atrocity scholarship, however much theorizing is completed, is to engage in a deep dialogue with cases selected, for it is these stories that should never be overlooked. It is critical to create empirically-precise, contextualized scholarship of mass atrocities while not forgoing the call to create theory. The perpetrating regimes of the three atrocities explored in this article are vastly different: a liberal democracy, a strong empire, and a crumbling empire which was reforming into a democracy. Despite the spatial, temporal, and regime type differences, perpetrators implemented similar DA crime processes. DA crimes are not limited to any particular regime type nor society - they can be implemented anywhere with the perpetration requirements outlined in this article. A major benefit of the structural approach to atrocities is the creation of strong middle-range theory in the style of the DA concept. If scholarship only examines single case studies or strives for meta-theoretical advances to apply to all atrocities, readily applicable typographical or killing process theories may be overlooked and sorely missing when they are needed to explain contemporary

\footnotetext{
${ }^{119}$ Hofmann, "Cumulative Genocide," 106 and Renée Hirschon, Heirs of the Greek Catastrophe: The Social Life of Asia Minor Refugees in Piraeus (New York: Berghahn Books, 2008), 2, 9-10, 25-26, and 37.
} 
crimes. The structural and comparative approach to atrocities should be explored in further scholarship.

\section{Acknowledgements}

I would like to thank Dr. Rhoda E. Howard-Hassmann, Dr. Maureen S. Hiebert, and the editors of Genocide Studies and Prevention for their invaluable and critical insights on this project.

\section{Bibliography}

Adalian, Rouben Paul. 2013. “The Armenian Genocide." In Century of Genocide: Critical Essays and Eyewitness Accounts, Fourth Edition. Edited by Samuel Totten and William S. Parsons, pages 117-157. New York: Routledge.

Akçam, Taner. 2006. A Shameful Act: The Armenian Genocide and the Question of Turkish Responsibility. New York: Henry Holy and Company, LLC.

Akçam, Taner. 2012a. The Young Turks' Crime Against Humanity: The Armenian Genocide and Ethnic Cleansing in the Ottoman Empire. Princeton, New Jersey: Princeton University Press.

Akçam, Taner. 2012b. “The Greek Deportations and Massacres of 1913-1914: A Trial Run for the Armenian Genocide." In The Asia Minor Catastophe and the Ottoman Greek Genocide. Edited by George Shirinian, pages 69-88. Bloomingdale, Illinois: The Asia Minor and Pontos Hellenic Research Centre, Inc.

Anderson, Benedict. 1985. Imagined Communities: Reflections on the Origin and Spread of Nationalism. Los Angeles: University of California Press.

Anderson, Gary Clayton. 2014. Ethnic Cleansing and the Indian: The Crime That Should Haunt America. Norman, Oklahoma: University of Oklahoma Press.

Apsel, Joyce. 2012. "Research and Teaching about Genocide: history, challenges and new directions." In Genocide Matters: Ongoing Issues and Emerging Perspectives. Edited by Joyce Apsel and Ernesto Verdeja, pages 1-15. New York: Routledge.

Arad, Yitzhak. 1999. Belzec, Sobibor, Treblinka: The Operation Reinhard Death Camps. Bloomington, Indiana: Indiana University Press.

Balakian, Peter. 2003. The Burning Tigris: The Armenian Genocide and America's Response. New York: HarperCollins.

Basso, Andrew R. 2013. "Dying as Exiles: Deportation Genocide Theory and the Relationship Between Displacement and Genocide." Unpublished Master's Thesis, Wilfrid Laurier University.

Basso, Andrew R. 2014. “Towards a Displacement Atrocities Theory: The Cherokee, Herero, and Pontic Greeks." Paper presented at the Eleventh Meeting of the International Association of Genocide Scholars, Winnipeg, Canada, July 17-19.

Berko, Jeffrey, et al. 2014. "Deaths Attributed to Heat, Cold, and Other Weather Events in the United States, 2006-2010." National Health Statistics Reports 76, pages: 1-15.

Bjørnlund, Matthias. 2012. "The Persecution of Greeks and Armenians in Smyrna, 1914-1916: A Special Case in the Course of the Late Ottoman Genocides." In The Asia Minor Catastophe and the Ottoman Greek Genocide. Edited by George Shirinian, pages 89-134. Bloomingdale, Illinois: The Asia Minor and Pontos Hellenic Research Centre, Inc.

Bobelian, Michael. 2012. Children of Armenia: A Forgotten Genocide and the Century-Long Struggle for Justice. New York: Simon \& Schuster.

Bridgman, Jon M. 1981. The Revolt of the Hereros. Los Angeles: University of California Press.

Bridgman, Jon M. and Leslie J. Worley. 2009. "Genocide of the Hereros." In Century of Genocide: Critical Essays and Eyewitness Accounts, Third Edition. Edited by Samuel Totten and William S. Parsons, pages 17-53. New York: Routledge.

Browning, Christopher. 1995. Ordinary Men: Reserve Police Battalion 101 and the Final Solution in Poland. New York: HarperCollins.

Bloxham, Donald and A. Dirk Moses. 2010. The Oxford Handbook of Genocide Studies. New York: Oxford University Press. http://dx.doi.org/10.1093/oxfordhb/9780199232116.001.0001 
Cartwright, Will. 1996. "Killing and Letting Die: A Defensible Distinction." British Medical Bulletin 52, no.2: pages 354-361. http://dx.doi.org/10.1093/oxfordjournals.bmb.a011550

Chalk, Frank and Kurt Jonassohn. 1990. The History and Sociology of Genocide: Analyses and Case Studies. New Haven, Connecticut: Yale University Press.

Cigar, Norman. 1995. Genocide in Bosnia: The Third Balkan War, Third Revised Edition. College Station, Texas: Texas A\&M University Press.

Conser, Walter H. 1978. "John Ross and the Cherokee Resistance Campaign." The Journal of Southern History 44, no.2: pages 191-212. http://dx.doi.org/10.2307/2208301

Cooper, Allan D. 2009. The Geography of Genocide. New York: University Press of America.

Cryer, Robert, et al. 2010. An Introduction to International Criminal Law and Procedure. New York: Cambridge University Press. http://dx.doi.org/10.1017/CBO9780511760808

Drechsler, Horst. 1980. "Let Us Die Fighting": The Struggle of the Herero and Nama Against German Imperialism (1884-1915). London: Zed Press.

Ehle, John. 1988. Trail of Tears: The Rise and Fall of the Cherokee Nation. New York: Doubleday Publishing Group, Inc.

Erichsen, Casper Wulff. 2008. "Forced Labour in the Concentration Camp on Shark Island." In Genocide in German South-West Africa: The Colonial War (1904-1908) in Namibia and its Aftermath. Edited by Jürgen Zimmerer and Joachim Zeller. Translated by Edward Neather, pages 84-99. Monmouth, Wales: The Merlin Press Ltd.

Feierstein, Daniel. 2012. "The Concept of 'Genocidal Social Practices'." In New Directions in Genocide Research. Edited by Adam Jones, pages 18-36. New York: Routledge.

Fein, Helen. 1993. Genocide: A Sociological Perspective. London: Sage Publications Ltd.

Fein, Helen. 1997. "Genocide by Attrition 1939-1993: The Warsaw Ghetto, Cambodia, and Sudan: Links between Human Rights, Health, and Mass Death." Health and Human Rights Vol. 2, No. 2: pages 10-45. http://dx.doi.org/10.2307/4065270

Fein, Helen. 1999. "Genocide and Gender: The Uses of Women and Group Destiny." Journal of Genocide Research Vol. 1, No. 1: pages 43-63. http://dx.doi.org/10.1080/14623529908413934

Fitch, C.H. 1900. "The Five Civilized Tribes: Indian Territory." Journal of the American Geographical Society of New York Vol. 32, No. 1: pages 15-21. http://dx.doi.org/10.2307/197278

Franks, Kenny A. 1979. Stand Watie and the Agony of the Cherokee Nation. Memphis, Tennessee: Memphis State University Press.

Friedländer, Saul. 2007. The Years of Extermination: Nazi Germany and the Jews. New York: HarperCollins.

Frowe, Helen. 2007. “Killing John to Save Mary: a Defence of the Moral Distinction Between Killing and Letting Die." In Topics in Contemporary Philosophy: Action, Ethics and Responsibility. Edited by Joseph Keim Campbell, et al., pages 47-66. Cambridge, Massachusetts: The MIT Press.

George, Alexander and Andrew Bennett. 2004. Case Studies and Theory Development in the Social Sciences. Cambridge, Massachusetts: MIT Press.

Gewald, Jan-Bart. 1999. Herero Heroes: A Socio-Political History of the Herero of Namibia 1890-1923. Athens, Ohio: Ohio University Press.

Green, Donald and Ian Shapiro. 1996. Pathologies of Rational Choice Theory: A Critique of Applications in Political Science. New Haven, Connecticut: Yale University Press.

Green, Michael D. 2005. The Cherokee Removal: A Brief History with Documents. New York: Bedford/ St. Martin's Press.

Halo, Thea. 2001. Not Even My Name: A True Story. New York: Picador.

Hatzfeld, Jean. 2005. Machete Season: The Killers in Rwanda Speak. New York: Farrar, Straus, and Giroux.

Hilberg, Raul. 1992. Perpetrators Victims Bystanders: The Jewish Catastrophe 1933-1945. New York: HarperCollins.

Hirschon, Renée. 2008. Heirs of the Greek Catastrophe: The Social Life of Asia Minor Refugees in Piraeus. New York: Berghahn Books.

Hoffmann, Peter. 1996. History of the German Resistance 1933-1945, Third Edition. Montreal, Quebec and Kingston, Ontario: McGill-Queen's Press. 
Hofmann, Tessa. 2011. "Cumulative Genocide: The Massacres and Deportations of the Greek Population of the Ottoman Empire (1912-1923)." In The Genocide of the Ottoman Greeks: Studies on the State-Sponsored Campaign of Extermination of the Christians of Asia Minor (19121922) and Its Aftermath: History, Law, Memory. Edited by Tessa Hofmann, et al., pages 39112. Sarsdale, New York: Melissa International Ltd.

Hull, Isabel V. 2005a. Absolute Destruction: Military Culture and the Practices of War in Imperial Germany. Ithaca, New York: Cornell University Press.

Hull, Isabel V. 2005b. "The Measure of Atrocity: The German War Against the Hereros: The Military Campaign in German Southwest Africa, 1904-1907." GHI Bulletin Vol. 37: pages 39-44.

Jones, Adam. 2000. "Gendercide and Genocide." Journal of Genocide Research Vol. 2, No. 2: pages 185-211. http://dx.doi.org/10.1080/713677599

Jones, Adam. 2011. Genocide: A Comprehensive Introduction, Second Edition. New York: Routledge.

Jones, Adam. 2012. "Genocide and Structural Violence." In New Directions in Genocide Research. Edited by Adam Jones, pages 132-152. New York: Routledge.

Katz, Steven T. 1994. The Holocaust in Historical Context: Volume 1: The Holocaust and Mass Death Before the Modern Age. New York: Oxford University Press.

Kaufman, Stuart J. 2001. Modern Hatreds: The Symbolic Politics of Ethnic War. Ithaca, New York: Cornell University Press.

Kévorkian, Raymond. 2011. The Armenian Genocide: A Complete History. London: I.B. Tauris \& Co.

Kiernan, Ben. 2007. Blood and Soil: A World History of Genocide and Extermination from Sparta to Darfur. New Haven, Connecticut: Yale University Press.

Kieser, Hans-Lukas. 2010. Nearest East: American Millennialism and Mission to the Middle East. Philadelphia: Temple University Press.

Klemperer, Klemens von. 1994. German Resistance Against Hitler: The Search for Allies Abroad 1938-1945. Oxford: Clarendon Press. http://dx.doi.org/10.1093/acprof:oso/9780198205517.001.0001

Kuper, Leo. 1982. Genocide: Its Political Use in the Twentieth Century. New Haven, Connecticut: Yale University Press.

Levene, Mark. 2005. Genocide in the Age of the Nation State, Vol.1: The Meaning of Genocide. London: I.B. Tauris.

Lieberman, Benjamin. 2012. "From Definition to Process." In New Directions in Genocide Research. Edited by Adam Jones, pages 3-17. New York: Routledge.

McLoughlin, William G. 1990. Champions of the Cherokees: Evan and John B. Jones. Princeton, New Jersey: Princeton University Press. http://dx.doi.org/10.1515/9781400860319

Mango, Andrew. 1999. Atatürk: The Biography of the Founder of Modern Turkey. New York: The Overlook Press.

Mann, Michael. 2005. The Dark Side of Democracy: Explaining Ethnic Cleansing. New York: Cambridge University Press.

Marx, Anthony. 1998. Making Race and Nation. New York: Cambridge University Press.

Mavrogordatos, George Th. 1983. Stillborn Republic: Social Coalitions and Party Strategies in Greece, 1922-1936. Los Angeles: University of California Press.

May, Larry. 2010. Genocide: A Normative Account. New York: Cambridge University Press.

Migdal, Joel. 1988. Strong Societies and Weak States: State-Society Relations and State Capabilities in the Third World. Princeton, New Jersey: Princeton University Press.

Miller, Robert J. 2006. Native America, Discovered and Conquered: Thomas Jefferson, Lewis Clark, and Manifest Destiny. Westport, Connecticut: Praeger Publishers.

Missall, John and Mary Lou Missall. 2004. The Seminole Wars: America's Longest Indian Conflict. Jacksonville, Florida: University of Florida Press.

Mooney, James. 2009. Historical Sketch of the Cherokee. New Brunswick, New Jersey: Transaction Publishers.

Mourelos, John. 2011. "The Persecutions in Thrace and Ionia in 1914 and the First Attempt at an Exchange of Minorities between Greece and Turkey." In The Genocide of the Ottoman Greeks: Studies on the State-Sponsored Campaign of Extermination of the Christians of Asia Minor (19121922) and Its Aftermath: History, Law, Memory. Edited by Tessa Hofmann, et al., pages 113136. Sarsdale, New York: Melissa International Ltd. 
Naimark, Norman. 2001. Fires of Hatred: Ethnic Cleansing in Twentieth-Century Europe. Cambridge, Massachusetts: Harvard University Press.

Papoutsy, Christos. 2008. Ships of Mercy: The True Story of the Rescue of the Greeks: Smyrna, September 1922. Portsmouth, New Hampshire: Peter E. Randall Publisher LLC.

Peel, Michael. 1997. "Hunger Strikes." BMJ Vol. 315, No. 7112: pages 829-830. http://dx.doi. org/10.1136/bmj.315.7112.829

Perdue, Theda and Michael D. Green. 2005. The Cherokee Removal: A Brief History with Documents. New York: Bedford/St. Martin's.

Prucha, F.P. 1969. “Jackson's Indian Policy: A Reassessment." The Journal of American History Vol. 56, No. 3: pages 527-539. http://dx.doi.org/10.2307/1904204

Quataert, Donald. 2001. "Labor History and the Ottoman Empire, c. 1700-1922." International Labor and Working-Class History Vol. 60: pages 93-109. http://dx.doi.org/10.1017/S014754790100446X

Reeves, Eric. 2005. "Genocide by Attrition: Agony in Darfur." Dissent Vol. 1, No. 218: pages 21-25. http://dx.doi.org/10.1353/dss.2005.0022

Rodhe, David. 1998. Endgame: The Betrayal and Fall of Srebrenica, Europe's Worst Massacre Since World War II. Boulder, Colorado: Westview Press.

Rosenberg, Sheri P. and Everita Silina. 2013. "Genocide by Attrition: Silent and Efficient." In Genocide Matters: Ongoing Issues and Emerging Perspectives. Edited by Joyce Apsel and Ernesto Verdeja, pages 106-126. New York: Routledge.

Rozema, Vicki. 2003. Voices from the Trail of Tears. Winston-Salem, North Carolina: John F. Blair, Publisher.

Sarkin, Jeremy. 2011. Germany's Genocide of the Herero: Kaiser Wilhelm II, His General, His Settlers, His Soldiers. Cape Town: UCT Press.

Schabas, William. 2008. "Genocide Law in a Time of Transition: Recent Developments in the Law of Genocide." Rutgers Law Review Vol. 61, No. 1: pages 161-192.

Scheffer, David. 2006. "Genocide and Atrocity Crimes." Genocide Studies and Prevention Vol. 1, No. 3: pages 229-250. http://dx.doi.org/10.3138/E832-0314-6712-60H3

Scheffer, David. 2007. "The Merits of Unifying Terms: 'Atrocity Crimes' and 'Atrocity Law'." Genocide Studies and Prevention Vol. 2, No. 1: pages 91-96. http://dx.doi.org/10.3138/q3714546-0t18-4462

Shaw, Martin. 2007. What is Genocide? Malden, Massachusetts: Polity Press.

Stanton, Gregory. "The Ten Stages of Genocide." Genocide Watch. Accessed 20 August 2015. http:// www.genocidewatch.org/genocide/tenstagesofgenocide.html.

Staub, Ervin. 2003. The Psychology of Good and Evil: Why Children, Adults, and Groups Help and Harm Others. New York: Cambridge University Press. http://dx.doi.org/10.1017/ CBO9780511615795

Stavridis, Stavros T. 2011. "International Red Cross: A Mission to Nowhere." In The Genocide of the Ottoman Greeks: Studies on the State-Sponsored Campaign of Extermination of the Christians of Asia Minor (1912-1922) and Its Aftermath: History, Law, Memory. Edited by Tessa Hofmann, et al., pages 277-296. Sarsdale, New York: Melissa International Ltd.

Straus, Scott. 2006. The Order of Genocide: Race, Power, and War in Rwanda. Ithaca, New York: Cornell University Press.

Sturgis, Amy H. 2007. The Trail of Tears and Indian Removal. Westport, Connecticut: Greenwood Press.

Stevenson, Angus and Maurice Waite (eds.). 2011. Concise Oxford English Dictionary. New York: Oxford University Press.

Suny, Ronald Grigor. 2011. "Writing Genocide: The Fate of the Ottoman Armenians." In A Question of Genocide: Armenians and Turks at the End of the Ottoman Empire. Edited by Ronald Grigor Suny, et al., pages 15-41. New York: Oxford University Press. http://dx.doi.org/10.1093/ acprof:osobl/9780195393743.003.0002

Thornton, Russell. 1984. "Cherokee Population Losses during the Trail of Tears: A New Perspective and a New Estimate." Ethnohistory Vol. 31, No. 4: pages 289-300. http://dx.doi. org/10.2307/482714

Totten, Samuel. 2012. Genocide by Attrition: The Nuba Mountains of Sudan. New Brunswick, New Jersey: Transaction Publishers. 
Travis, Hannibal. 2006. “'Native Christians Massacred': The Ottoman Genocide of the Assyrians during World War I." Genocide Studies and Prevention Vol. 1, No. 3: pages 327-371. http://dx.doi.org/10.3138/yv54-4142-p5rn-x055

Travis, Hannibal. 2010. Genocide in the Middle East: The Ottoman Empire, Iraq, and Sudan. Durham, North Carolina: Carolina Academic Press.

United Nations. 1948. Convention on the Prevention and Punishment of the Crime of Genocide. 9 December 1948. United Nations Treaty Series Vol. 78, No. 1021.

United Nations. 1998. Rome Statute of the International Criminal Court (last amended 2010). 17 July 1998. ISBN No. 92-9227-227-6.

United States Congress. 1830. Indian Removal Act. Twenty-First Congress, Sess. 1, Ch. 148. Library of Congress. 28 May 1830.

United States Department of the Interior. 1992. National Register of Historic Places, Multiple Documentation Form: Historic and Historical Archaeological Resources of the Cherokee Trail of Tears. OMB No.1024-0018.

Waller, James. 2007. Becoming Evil: How Ordinary People Commit Genocide and Mass Killing. New York: Oxford University Press.

Weiker, Walter F. 1968. "The Ottoman Bureaucracy: Modernization and Reform." Administrative Science Quarterly Vol. 13, No. 3: pages 451-470. http://dx.doi.org/10.2307/2391053

Weisman, Brent R. 2007. "Nativism, Resistance, and Ethnogenesis of the Florida Seminole Indian Identity." Historical Archaeology Vol. 41, No. 4: pages 198-212.

Wiess-Wendt, Anton. 2010. “The State and Genocide." In The Oxford Handbook of Genocide Studies. Edited by Donald Bloxham and A. Dirk Moses, pages 81-101. New York: Oxford University Press. http://dx.doi.org/10.1093/oxfordhb/9780199232116.013.0005

Wellington, J.H. 1967. South West Africa and its Human Issues. Oxford: Clarendon Press.

Werfel, Franz. 2012. The Forty Days of Musa Dagh. Translated by Geoffrey Dunlop and James Reidel. New York: Caroll \& Graf.

Werth, Nicholas. 2010. "Mass Deportations, Ethnic Cleansing, and Genocidal Politics in the Later Russian Empire and the USSR." In The Oxford Handbook of Genocide Studies. Edited by Donald Bloxham and A. Dirk Moses, pages 386-406. New York: Oxford University Press. http://dx.doi.org/10.1093/oxfordhb/9780199232116.013.0020

Wilkins, Thurman. 1970. Cherokee Tragedy: The Story of the Ride Family and the Decimation of a People. London: Collier Macmillan Ltd.

Woodward, Grace Steele. 1963. The Cherokees. Oklahoma: University of Oklahoma Press.

Worcester v. Georgia, 31 U.S. 515 (1832).

Zimmerer, Jürgen. 2008a. “The Model Colony? Racial Segregation, Forced Labour, and Total Control in German South-West Africa." In Genocide in German South-West Africa: The Colonial War (1904-1908) in Namibia and its Aftermath. Edited by Jürgen Zimmerer and Joachim Zeller. Translated by Edward Neather, pages 19-37. Monmouth, Wales: The Merlin Press Ltd.

Zimmerer, Jürgen. 2008b. “War, Concentration Camps and Genocide in South-West Africa: The First German Genocide." In Genocide in German South-West Africa: The Colonial War (1904-1908) in Namibia and its Aftermath. Edited by Jürgen Zimmerer and Joachim Zeller. Translated by Edward Neather, pages 41-63. Monmouth, Wales: The Merlin Press Ltd.

Zürcher, Erick J. 2002. "Ottoman Labour Battalions in World War I." In The Armenian Genocide and the Shoah. Edited by Hans-Lukas Kieser and Dominik J. Schaller, pages 187-195. Zürich, Switzerland: Chronos-Verlag.

Zürcher, Erick J. 2004. Turkey: A Modern History, Revised Edition. New York: I.B. Tauris.

Zürcher, Erick J. 2010. The Young Turk Legacy and Nation Building: From the Ottoman Empire to Atatürk's Turkey. New York: I.B. Tauris \& Co Ltd. 